\title{
Rationalizing Restitution
}

\author{
Andrew Kull $\uparrow$
}

Significant uncertainty shrouds the modern law of restitution. Few American lawyers, judges, or law professors are familiar with even the standard propositions of the doctrine, and the few who are continue to disagree about elementary issues of definition. This Article argues that the law of restitution will remain inaccessible until these issues are resolved; and that the way to resolve them is to follow the basic proposition of modern restitution to its logical conclusion. This means describing the subject exclusively in terms of liability for unjust enrichment. To this end, the author argues (i) that the supposed instances of "restitution without enrichment," described in a celebrated article by John Dawson, are not in fact instances of restitution at all; (ii) that "specific restitution" bears no useful relation to the law of unjust enrichment; and (iii) that restitution should not be viewed as a remedial option, because it constitutes an independent basis of liability (comparable to contract and tort) having characteristic remedies of its own. In a concluding section the author indicates some areas of the law, notably the law governing mistaken payments, in which a "rationalized" law of restitution might change outcomes in litigated cases.

\section{INTRODUCTION}

What is restitution anyway, and why does it matter? The subject I want to address is the body of law concerned with liability based on unjust enrichment. For many lawyers the immediate connotation of the word "restitution" will be something else entirely: criminal sanctions requiring wrongdoers to make restitution to their victims, a topic having almost nothing to do with the subject at hand. ${ }^{1}$ The linguistic confusion that bedevils the law of restitution-necessitating laborious definitions before anyone

Copyright (c) 1995 Califomia Law Review, Inc.

$\dagger$ Professor of Law, Emory University. For their helpful criticism of this article at various stages of its preparation, the author is indebted to Jennifer Arlen, John W. Carter, Gareth Jones, Douglas Laycock, James Lindgren, Jeffrey Pennell, and Christopher Wonnell. Successive versions of this article were presented to law faculty colloquia at Emory University, Chicago-Kent College of Law, Boston University, and the University of San Diego; comments by participants have been responsible for numerous improvements.

1. "Restitution" in this context is primarily a form of compensation, though it might serve the incidental purpose of causing a wrongdoer to disgorge ill-gotten gain. See, e.g., Iowa CoDE $\$ 910.1(3)$ (1995) (" 'Restitution' means payment of pecuniary damages to a victim in an amount and in the manner provided by the offender's plan of restitution."). 
can understand what you are talking about-affords an early indication that the common name of this neglected body of law was singularly ill-chosen.

The modern law of restitution was invented by the American Law Institute, in the sense that the law of contracts and the law of torts were invented by the nineteenth-century treatise writers. The Restatement of Restitution, "adopted and promulgated" in 1936, explored the consequences of one all-important insight. Like other legal systenis, Anglo-American law has long imposed liability based on what it calls unjust enrichment: the obligation to account for certain benefits (though not others) obtained at the expense of another party. Yet the common law, organized for centuries in terms of remedies rather than theories of liability, rarely acknowledged the avoidance of unjust enrichment as one of its actuating principles. ${ }^{2}$

The great accomplishment of Warren Seavey and Austin Scott, the "reporters" of the Restatement of Restitution, was to demonstrate that a range of seemingly disparate rights and remedies could in fact be explained, and usefully explained, in terms of the common objective of preventing unjust enrichment. Not only quasi-contract and constructive trust, the twin pillars of restitution in law and equity, but a host of other remedial possibilities, including indemnity, contribution, subrogation, and equitable liens, could be seen to share this fundamental rationale. Recognition of their common legal purpose made the workings of these areas of the law easier to understand. Neither the correctness nor the value of this central insight, it seems fair to say, has ever been challenged, and it remains one of the most influential achievements of American private law.

A complete account of civil liability in our legal system requires the mclusion of restitution or some functional equivalent, because there are important instances of liability that contract and tort, conventionally defined, cannot adequately explain. In some cases, a theory of unjust enrichment provides the only available explanation of why the defendant is liable at all. A person who receives $\$ 200$ (or $\$ 200$ million) through a "bank error in your favor" is normally obliged to repay the money. Liability cannot be in orthodox tort, since the passive recipient has breached no mdependent duty; ${ }^{3}$ nor can it be in contract, since the recipient has promised nothing (and may indeed be a total stranger to the bank). The conventional explanation is to say that the recipient would be unjustly enriched if he retained the money. The same theory, liability to account for unjust

2. Were it not for Lord Mansfield, one would say "never." The rationale of modern restitution is commonly traced to Mansfield's statement in Moses v. Macferlan, 2 Burr. 1005, 97 Eng. Rep. 676 (K.B. 1760):

In one word, the gist of this kind of action is, that the defendant, upon the circumstances of the case, is obliged by the ties of natural justice and equity to refund the money.

Id. at 1012, 97 Eng. Rep. at 681 .

3. The recipient of a mistaken payment is not liable in conversion where the money obligation cannot be "described or identified as a specific chattel." Conversion will not lie for an "incorporeal right to a eertain sum." See 1 Fowler V. HARPER ET AL., THE LAw OF TORTS $\$ 2.13 \&$ n.8 (2d ed. 1986). 
enrichment, explains why the victim of a tort or other wrong may be able to recover an amount in excess of his injury: as when a trademark or copyright owner, having suffered no damage, recovers some or all of an infringer's profits; or when the victim of an embezzler recovers the appreciated value of the property in which his money was invested. Whenever the law gives a remedy measured by the defendant's gam rather than plaintiff's loss, a duty to disgorge unjust enrichment will explain the defendant's liability more readily (and at any rate more completely) than will a duty merely to refrain from injuring others.

This law of benefit-based obligations currently faces major difficulties, both theoretical and practical. The threshold problem confronting the American law of restitution, closely related to the linguistic confusion already mentioned, is one of definition. While most observers will concede (more or less) what has been said so far about liability based on unjust enrichment, there remains a serious controversy over the proper relation between unjust enrichment and the law of restitution. Is restitution-or ought it to be-the law of unjust enrichment, pure and simple? Is it unjust enrichment and something else besides: restitution in the sense of restoration or giving back? (If it means both these things, then what is the relation between the two meanings?) Is unjust enrichment a legitimate unifying principle for this body of law, or is it at best no more than "a convenient explanation of specific results"4 among "a truly superlative collection of jurisprudential loose ends"s - employed to unwind, reverse, or pick up the pieces after anomalous transactions of one kind and another?

The modern consensus puts unjust enrichment at the heart of liability in restitution, ${ }^{6}$ so the question, simply put, is whether restitution properly includes anything else. Resolution of this controversy is not solely a matter of orderly classification, because it will affect the definition of the prima facie case for recovery in restitution. Must a restitution plaintiff allege that the defendant has actually been enriched by the transaction in question, or will it be enough to show that the defendant has obtained a benefit (at plaintiff's expense) to which he has an insufficient legal entitlement? In some cases, admittedly, the answer to this question will determine only how a defendant's liability is explaimed; but in others, it will decide the issue of liability itself. For example, a plaintiff alleging a material breach of a con-

4. JOHN P. DAwSON, UNJUST ENRICHMENT 8 (1951).

5. Philip Mechem, A Realistic Treatment of Restitution, 25 IowA L. Rev. 187, 190 (1939) (book review).

6. Leading American authorities for the view that the law of restitution is (at least predominantly) the law of unjust enrichment include the RESTATEMENT OF RESTITUTION ch. 1 (1936); 1 George E. Palmer, The Law of Restitution \& 1.1 (1978); Dan B. Dobbs, Law of Remedies $\$ 4.1$ (2d ed. 1993). See also Restatement (SeCond) of Restitution $\$ 1$ (Tentative Draft No. 1, 1983). The prevailing notion is summed up by Stewart Macaulay's statement, "Restitution is the study of unjust enrichment," with the appended footnote, "Of course, this is only substantially true." Stewart Macaulay, Restitution in Context, 107 U. PA. L. REv. 1133, 1133 \& n.2 (1959). 
tract that he had been performing at a loss may have either a valuable claim in restitution or else no claim at all, depending on whether the function of restitution is to unwind certain imperfect transactions or to prevent unjust enrichment. $^{7}$

Principal authorities for the unjust-enrichment conception, including most notably the Restatement itself, appear to accept the idea that the act of restoration forms at least a subsidiary part of the law of restitution, despite the fact that the restoration remedies (replevin, ejectment, and so forth) operate without regard to the defendant's enrichment. ${ }^{8}$ Leading American scholars of restitution, moreover, have questioned whether unjust enrichment is even central to this body of law. The last of John Dawson's many contributions to the field was an article arguing that the most characteristic restitution remedies do not depend on any showing that the defendant has been enriched in the ordinary sense of the word. ${ }^{9}$ Douglas Laycock, who accepts the standard account of the unjust-enrichment side of restitution, argues that it constitutes only half the picture. He sees the restoration remedies, or restitution in specie, as "part of the core concept of restitution . . . conceptually equal to the avoidance of unjust enrichment."10 Both positions are reflected in the views of those writers on contracts who argue that restitution, when employed as a remedy for breach, is concerned not with unjust enrichment but with the restoration of the nonbreaching party to the status quo ante. ${ }^{11}$

Disagreement at this basic level about the content of the law of torts or the law of contracts would be unthinkable-not because these subjects have an immanent or ideal form (any more than restitution does), but because they have acquired stable conventional definitions (as restitution has yet to do). The nineteenth-century treatise writers defined bodies of law called "torts" and "contracts" that lawyers came to regard as appropriate, because the subjects as defined lent themselves to fruitful analysis and analogy. ${ }^{12}$ By contrast, in the area of liability for unjust enrichment-for reasons that

7. See Andrew Kull, Restitution as a Remedy for Breach of Contract, 67 S. CAL. L. Rev. 1465, 1478-83 (1994) (if restitution means liability for unjust enrichment it ean have no application in this context, because a breach of contract does not enrich the defaulting party). Other settings in which the relation of defendant's enrichment to the prima facie case in restitution may decide the question of liability vel non are suggested in Part IV, infra.

8. See, e.g., RESTATEMENT OF RESTITUTION 523 (1936) (Introductory Note) (characterizing the actions of replevin and ejectment as "restitutionary" in that they "restore to the possession of the owner property of which he was deprived").

9. See John P. Dawson, Restitution Without Enrichment, 61 B.U. L. Rev. 563, 577 (1981).

10. Douglas Laycock, The Scope and Significance of Restitution, 67 TEx. L. Rev. 1277, 1280 (1989).

11. "[A] ]though courts have tended to give their obeisance to the unjust enrichment theory of restitution, the undercurrent of their decisions has flowed into broader channels: the restoration of the status quo ante." Joseph M. Perillo, Restitution in a Contractual Context, 73 Colum. L. Rev. 1208, 1222 (1973). See also the authorities eited infra at note 89.

12. We tend to take this work of definition for granted, and it is easy to forget how recently it was completed. Tort law was an especially late discovery. Reviewing one of the earliest torts treatises in 
were more circumstantial than substantive-this threshold task of definition was not pursued to a conclusion when the rest of the legal landscape was being given its modern shape. ${ }^{13}$ The result has been a persistent uncertainty about this part of the law that continues to hamper analysis and even comprehension.

Confusion over the content of restitution carries significant adverse consequences. To put it bluntly, American lawyers today (judges and law professors included) do not know what restitution is. The subject is no longer taught in law schools, ${ }^{14}$ and the lawyer who lacks an introduction to its basic principles is unlikely to recognize them im practice. The technical competence of published opinions in straightforward restitution cases has noticeably declined; judges and lawyers sometimes fail to grasp the rudiments of the doctrine even when they know where to find it. ${ }^{15}$ Cases

1871, the young Oliver Wendell Holmes showed how easy it was to quarrel with the definition of the new subject:

We are inclined to think that Torts is not a proper subject for a law book. Under this title we expect to find some or all of the wrongs remedied by the actions of trespass, trespass on the case, and trover. But we cannot help believing that the cohesion or legal relationship, say, of trespass quare clausum, is closer with the duties to him in possession enforced by real actions, than with assault and battery. So, to give another example, the law of actions for deceit seems to us to be properly presented in connection with that of estoppel in pais as two forms of sanction for the same duty-not to defraud one's neighbor, to put it broadly. Seduction, which we find in the next chapter of this book, belongs at the other end of the corpus juris.

Book Notices, 5 AM. L. Rev. 340, 341 (1871) (reviewing C.G. Addison, THE LAw of ToRTs (abridged ed. 1870)), reprinted in 1 The Collected Works of Justice Holmes 237 (Sheldon M. Novick ed., 1995).

13. The arrested development of restitution doctrine appears to be, as Peter Birks has suggested, largely a historical accident, the result of clumsy classification. Its principal legal component, the action in quasi-contract, was long treated as an appendix to the law of contracts; equity's main contribution, the constructive trust, was (with equal illogic) regarded as a subcategory of trusts. See PETER BIRKS, AN InTRODUCTION TO THE LAW OF Restrumtion 4-5 (1985). By the time the Restatement of Restitution proposed a synthesis on unjust-enrichment lines, the work of treatise-writing further needed to shape and solidify the doctrine had already fallen out of favor with Ameriean law professors. See generally A.W.B. Simpson, The Rise and Fall of the Legal Treatise: Legal Principles and the Forms of Legal Literature, 48 U. Chr. L. REv. 632 (1981). When George Palmer's encyclopedic Law of Restrumtion was finally published in 1978 , its unfamiliar concepts had become inaccessible to much of the American legal profession.

14. Only a bare handful of American law schools offer an independent course in Restitution today, but a generation ago it was still a standard part of the curriculum. In 1964-1965, for example, sixty-four members of a far smaller law-teaching profession identified themselves as teachers of Restitution. By this measure, Restitution resembled courses like Antitrust (also 64 teachers) or Admiralty (52); it compared respectably even to a popular offering like Sales (100), while coming in well ahead of Securities Regulation (37). See Directory of Law Teachers in American Bar Association Approved Law Schools (West Publishing Co. ed. 1965).

15. For a striking example, consider the opinion-by a distinguished panel-in United States v. Consolidated Edison Co., 580 F.2d 1122 (2d Cir. 1978). The Atomic Energy Commission had supplied electricity to Con Ed, during a power shortage, pursuant to an agreement that was held to be unenforceable under the Statute of Frauds. Id. at 1123-24. Rescuing bargains from the Statute of Frauds is one of the traditional uses of restitution, see 2 PALMER, supra note 6, ch. 6, and the facts of the case invited a straightforward argument that Con Ed would be unjustly enriched if it did not pay at least a substantial part of what the government demanded. The court identified restitution as the basis of Con Ed's liability, but it explained that liability in this case was a function of what it called the "emergency 
involving classic restitution scenarios may be argued and decided without any apparent recognition - by the court or by counsel - that principles of unjust enrichment might have a bearing on the issues at hand. ${ }^{16}$ The same lack of familiarity causes restitution cases to be decided on increasingly narrow grounds, cut off from (and contributing nothing to) the broader law of unjust enrichment that was the Restatement's great discovery.

No legal topic can long survive this degree of professional neglect. Unless the means are found to revive it, restitution in this country may effectively revert to its pre-Restatement status, in which problems of unjust enrichment were treated in isolation, classified only by transactional or remedial setting: Mistake, Indemnity, Trustees, Subrogation. The loss to American law, measured im terms of its ability to yield coherent and reasoned adjudication, has already been very great, and the outlook is not encouraging.

My proposition is that the law of restitution be defined exclusively in terms of its core idea, the law of unjust enrichment. By this definition it would be axiomatic (i) that no liability could be asserted in restitution other than one referable to the unjust enrichment of the defendant, and (ii) that the measure of recovery in restitution must in every case be the extent of the defendant's unjust enrichment. These axioms are already consistent with the outcome of most American restitution cases; our difficulty has been less in knowing what to do than in understanding why we were doing it. Marginal restitution cases, inconsistent with one or both of the foregoing

assistance doctrine": the proposition (codified in $\S 115$ of the Restatement of Restitution) that a plaintiff has a claim in restitution for goods or services supplicd in performance of a duty of the defendant, without defendant's knowledge or consent, where the plaintiff's intervention was necessitated by a public health or safety emergency. Consolidated Edison, 580 F.2d at 1127. The "doctrine" thus invoked had not the remotest applicability to the case at hand-one in which the defendant had sought the plaintiff's intervention and agreed to pay for it-and a court that was comfortable with the basic propositions of the Restatement of Restitution would never have attempted to force the case into such an ill-fitting rationale. (The Restatement's illustrations of the function of $\S 115$, by contrast, involve such matters as the burial of the dead or the removal of obstructions from a public highway after the persons responsible have refused to act. See Restatement of Restitution $\$ 155 \mathrm{cmt}$. b (1936).) Indeed, the court's manifest unfamiliarity with elementary unjust-enrichment principles was underscored in a footnote:

Finally under one of the Government's two quasi-contractual theories-that of unjust enrichment - it is hard to see what type of uncompensated-for benefit Con Edison has retained which it might disgorge: it has utilized the power furnished; that power is no more. Unjust enrichment in the ordinary sense does not appear to us to be a satisfactory rubric of analysis for the case.

Consolidated Edison, 580 F.2d at 1126 n.7.

16. One particularly dramatic example was the celebrated litigation over "the $\$ 92$ million typo," in which a typist's inadvertent omission of three zeros from a financing statement was alleged to have reduced the amount of an otherwise valid first mortgage from $\$ 92,885,000$ to $\$ 92,885$. Litigation inspired by this transparent and inconsequential error resulted in five published judicial opinions, none of which expressly acknowledged the relevance of restitution doctrine or unjust enrichment to the problem before the court. E.g., Prudential Ins. Co. of Am. v. S.S. American Lancer, 686 F. Supp. 469 (S.D.N.Y. 1988), aff'd, 870 F.2d 867 (2d Cir. 1989). For a fuller account of the "missing zeros" episode, see Andrew Kull, Zero-Based Morality, Bus. L. TODAY, July/Aug. 1992, at 11. 
axioms, will henceforth require either a different rationale or a different result.

The case for a purely enrichment-based law of restitution is in one sense no more than a hunch. I suggest that a law of restitution, pruned back to its central conception, would be at once more comprehensible and more accessible. With renewed accessibility and corresponding professional attention, the subject might flourish again in the United States as it now docs elsewhere in the common-law world. ${ }^{17}$ I cannot prove that these consequences will follow from a rationalization of restitution doctrine, but to anyone concerned with the future of the subject, I suggest that it's worth a try.

Arguing for enrichment-based restitution requires that we consider what would be left out. What liabilities would be excluded from the subject by our new definition? Are they readily (or perhaps better) classified elsewhere? What outcomes in restitution cases might need to be reconsidered? Two major objections stand in the way of the proposed rationalization. If it were true, either that restitution is not essentially concerned with unjust enrichment (as John Dawson ultimately claimed), or that there is a restoration component of restitution "conceptually equal to the avoidance of unjust enrichment" (as Douglas Laycock has argued), then to define restitution exclusively in terms of unjust enrichment would be counterproductive and intellectually perverse. The next two Sections of this Article take up these objections in turn.

Part I examines Dawson's alleged instances of "restitution without enrichment" and concludes that they were not restitution in the first place. More specifically, Dawson's examples of restitution without enrichment all derive from the use of restitutionary forms as means of contract enforcement. But the uses of "restitution" in this context are better understood as part of the ordinary working of contract law. Moreover, because the unjust enrichment that is the predicate of liability in restitution can only be determined, in a contractual context, by reference to the parties' agreement, I will conclude that a rationalized law of restitution-a law of restitution based exclusively on unjust enrichment-has no independent role to play in legal disputes arising out of enforceable contracts. Because traditional accounts of restitution have accorded considerable importance to contract

17. The enfeebled state of American restitution stands in sharp contrast to the situation in England, Canada, Australia, and the Commonwealth generally. In all of these countries, restitution (on a conceptual model visibly derived from the ALI Restatement) currently enjoys belated but unprecedented judicial attention and academic favor. The reasons for the difference invite speculation but lie outside the scope of this Article. The wealth of recent work on restitution by British and Commonwealth scholars was largely inspired by the treatise of Goff and Jones, first published in 1966; the current edition is Lord Goff of Chieveley \& Gareth Jones, The Law of Restitution (4th ed. 1993). Other notable works include J. BEATSON, THE USE AND ABUSE OF UNJUST ENRICHMENT (1991); Birks, supra note 13; Andrew Burrows, The Law of Restitution (1993); Peter D. Maddaugh \& John D. McCamus, The Law of Restitution (1990). 
remedies in restitutionary guise, their elimination from the definition of "restitution" would account for the greatest change in the outward appearance of a rationalized body of law.

Responding in part to Laycock's well-known description of the subject, Part II looks at the role of restoration in the law of restitution: both restoration of a thing to a plaintiff, as in "specific restitution," and restoration of a plaintiff to a previous state of affairs, as in "return to the status quo ante." Legal remedies having the effect of restoring and returning do not constitute, as does unjust enrichment, an independent basis of liability, and such remedies bear no essential or even useful relation to the avoidance of unjust enrichment. Their supposed connection to enrichment-based rcstitution is the result of a mistake committed by Seavey and Scott in 1936, when they chose the word "restitution" to describe liability based on unjust enrichment. The conceptual overlay between unjust enrichment, on the one hand, and the restoration remedies, on the other, has been no more than an unintended consequence of that initial error in semantic judgment. By abandoning the futile effort to find a relation between two unrelated concepts, we can remove the single biggest obstacle to a rationalized statement of the law of unjust enrichment.

Part III turns briefly to address a subsidiary question: the necessity or desirability of identifying circumstances in which enrichment-based restitution plays a "remcdial" as opposed to a "substantive" role. Where a tort victim can claim an alternative remedy measured by the benefit to the defendant rather than the loss to the plaintiff (as in the standard case of "waiver of tort and suit in assumpsit"), is it appropriate to conclude that this is a setting in which restitution is remedial rather than substantive? In other words, does restitution here supply an enrichment-based remedy for a liability in tort? Or is it preferable, on the contrary, to regard a remedy in which the plaintiff's recovery is measured by the defendant's gain as the hallmark of a liability founded on unjust enrichment? The question is subsidiary because it is purely a matter of organization: no outcome as to liability or remedy will be affected by the label we choose. Yet the answer will significantly influence our idea of what constitutes, conceptually, the coninion denominator of the law of restitution.

Finally, Part IV suggests some ways in which a rationalized law of restitution might in fact change case outcomes. Different results are most likely in cases of restitution for benefits conferred by mistake, because courts in that area have not always insisted on the unjust enrichment of the defendant as an indispensable part of the plaintiff's prima facie case. A nore consistent focus on the defendant's enrichment as the basis of liability should also inspire a reexamination of the affirmative defenses to restitution. As currently formulated, the affirmative defenses shield from liability certain defendants who are manifestly enriched by the transactions at issue, while failing to protect others whose real enrichment appears questionable. 
(The very substantial liabilities that can turn on our understanding of the affirmative defenses to restitution are illustrated by recent cases involving misdirected electronic funds transfers between banks.) Cases that directly put in issue either the prima facie case in restitution or the nature of the affirmative defenses are admittedly not common. Their resolution is of vital importance, however, because it requires an explicit judgment about restitution's underlying rationale.

I

\section{RESTITUTION Without ENRICHMENT}

Announcing that his purpose was "to join in celebrating" the recent publication of George Palmer's four-volume treatise on The Law of Restitution, ${ }^{18}$ the late John Dawson published in 1981 a brilliant and misleading article entitled "Restitution Without Enrichment."19 The purported Festschrift offered by one of the country's two leading restitution scholars to the other was soinething of a poisoned apple. The heart of Dawson's article is a catalogue of cases in which a liability described as restitutionary was imposed on defendants who could realistically deny that the transactions in question had enriched thein in any ordinary sense of the word. The avowed, subversive purpose of Dawson's catalogue was to demonstrate the futility of organizmg "the law of restitution" around the unifying concept of unjust enrichment ${ }^{20}$ - the premise that was Palıner's explicit and indispensable starting point. The unstated further inplications of Dawson's argument, there being no obvious alternative to unjust enrichment as an organizing principle, hinted at the futility of writing a treatise on "the law of restitution" in the first place.

Dawson's iconoclastic object was, as he put it, "to show that in nost of the standard work they do restitution remedies in American law do not depend in any way on a showing that someone has been or will be 'enriched' in anything like [the] sense of an increase in aggregate wealth."21 To justify this paradoxical assertion, Dawson put at center stage a probleinatical set of cases-those in which the forms of restitution are employed as remedies in contract disputes-while relegating to secondary status the body of law that best reflects the ordinary workings of restitution. The heart of restitution comprises a set of rules to regulate transfers that take place in the absence of an enforceable contract: benefits that are taken without permission, or conferred without request, or conferred by mistake. In all of these instances, as Dawson concedes, remedy and liability coincide: because the basis of liability is unjust enrichment, the ineasure of recovery is defendant's gain, not plaintiff's loss. By contrast, in what he

\footnotetext{
18. PALMER, supra note 6.

19. Dawson, supra note 9, at 565.

20. See id. at 577.

21. Id.
} 
saw as the real work of restitution- "the unwinding of contracts; actual or supposed"22 - Dawson noted that restitution simply required the defendant to "restore whatever was given or done in response to and in conformity with [the terms of the exchange,] and it will not matter in the slightest degree whether this had brought profit or advantage to him."23

If this were an accurate statement about the "standard work" performed by the restitution remedies in American law, Dawson's demonstration would, as he fully intended, seriously or fatally undermine any attempt at an explanation of restitution in terms of unjust enrichment. In fact, Dawson got things exactly backwards. Rules that govern nonconsensual transfers account for the bulk of restitution law and certainly reflect the mainstream of restitution doctrine. ${ }^{24}$ Dawson's search for instances of restitution without enrichment led him to focus on a narrow group of cases, those that unwind incomplete consensual exchanges, in which the law's observed response is far more easily described as imposing a liability in contract. The short answer to most of Dawson's examples of restitution without enrichment is therefore that they are not restitution at all. Each is an example, rather, of surreptitious contract enforcement.

The fact that "restitution without enrichment" is persistently observed in the context of contract is indicative of a broadcr analytical problem. Looking more closely at the settings in which a purported remedy in restitution actually does the work of contract, we will perceive a fundamental incompatibility between liability in restitution and any dispute arising from the performance or discharge of a valid contractual obligation. Restitution is analytically unsuited for the resolution of most contract disputes, because where a benefit is conferred pursuant to a valid contract, the presence or absence of unjust enrichment-the starting point of analysis in restitution-can only be determined by reference to the parties' bargain. Because a voluntary agreemcnt fixes the baseline of enrichment as between the parties, the existence of a valid contract to govern a particular transaction normally establishes a boundary beyond which liability in restitution cannot extend.

The tendentious character of Dawson's argument will appear more clearly if we consider, briefly, the central remedial proposition of orthodox restitution: that the standard measure of recovery is the benefit to the defendant rather than the cost to the plaintiff. ${ }^{25}$ This important limit on the restitutionary claiin appears most plainly in cases where the cost to the

22. Id.

23. Id. at 582 .

24. To take one crude but simple measure of legal bulk, the law of benefits wrongfully obtained, or conferred by mistake, or otherwise conferred in the absence of an enforccable contract between the parties, occupies nineteen of the twenty-three chapters of Palmer's treatise. Restitution for benefits conferred pursuant to an enforceablc contract occupies three chapters. Dawson's examples of "Testitution without enrichment" can all be found in those three chapters of Palmer.

25. See infra notes 28-35. 
plaintiff of conferring a benefit is greater than its value in the hands of the defendant. The centrality of the rule that limits recovery to "benefit conferred" makes it plain that the cases chosen by Dawson to illustrate "restitution without enrichment," cases which do not follow the rule, form a category that is fundamentally anomalous. The anomaly is explained when we observe that Dawson's cases enforce a liability based, not on defendant's enrichment, but on defendant's promise.

\section{A. Value-Reducing Transfers}

Value is intransitive. An object worth $\$ 100$ to me (or costing $\$ 100$ to produce) may be worth $\$ 10$ to you or indeed nothing at all. The ineluctable contingency of value can result in a marked disparity between the cost of conferring a benefit and its value in the hands of the recipient. The consequences are significant for a theory of legal liability originating in defendant's enrichment. If the restitutionary inpulse steins from the identification of value that a defendant is obliged by the ties of natural justice and equity to refund, it would seein as an initial inatter that liability should be limited in every case to the net value of the benefit to a person in defendant's position. $^{26}$

Where the law imposes an obligation to pay for benefits conferred in the absence of contract, the ordinary ineasure of recovery is therefore defendant's gam, not plaintiff's cost. The distinction is blurred in soine factual settings, but only because plaintiff's out-of-pocket expenditure (or custoinary charge) sometimes serves as the inost accurate ineasure of the benefit conferred. ${ }^{27}$ In other situations, where the possibility of unprofit-

26. Every dollar of liability in excess of the subjective value to the defendant must (by definition) leave the defendant worse off than he was before he received the benefit in question. Such a liability might be justified by a duty to compensate the plaintiff for his expenditure (if there were such a duty), but it cannot be satisfactorily explained by a duty to disgorge unjustified enrichment.

27. Thus where a physician renders services in an emergency to an unconscious patient, it is logical, not only to measure the benefit in restitution by the physician's customary charge, but also to recognize the same benefit whether the patient lives or dies. See Cotnam v. Wisdom, 104 S.W. 164, 166 (Ark. 1907) (doctor rendered emergency services to unconscious patient who died without regaining consciousness). Not only does the unconscious patient obtain the same services as the conscious patient, but the conscious patient will normally undertake to pay the same fee without regard to the medical outcome. If, therefore, the proper measure of enrichment (in the case of an innocent recipient) is what the defendant would have paid in the voluntary transaction that represents our ideal standard of exchange values, the cases are correct in awarding the surgeon's customary fee, whether the outcome is successful or not. But see Christopher T. Wonnell, Replacing the Unitary Principle of Unjust Enrichment, 45 Emory L.J. (forthcoming Winter 1996) ("fictional" to equate surgeon's recovery with benefit to the patient). A mirror-image question about the measure of enrichment arises where the defendant has made profitable but unauthorized use of the plaintiff's property; here the choice lies between the rental value of the property, on the one hand, and a full accounting for profits on the other. Where the conversion or trespass is inadvertent or involuntary, we might conclude that the defendant's enrichment is unjust only to the extent of the consideration he would have paid in the voluntary transaction that ideally would have taken place. The problem is illustrated by such famous cases as Edwards v. Lee's Adm'r, 96 S.W.2d 1028 (Ky. 1936) (trespass to underground cave inaccessible from plaintiff's land); Olwell v. Nye \& Nissen Co., 173 P.2d 652 (Wash. 1946) (unauthorized use of egg- 
able expenditure is a matter of everyday experience, the limitation of the plaintiff's restitutionary recovery to the amount of the benefit to the defendant becomes a visible theme of the decisions.

Thus a co-tenant who makes improvements to land, without obtaining the agreement of fellow co-tenants to share $m$ the cost, will have a claim in restitution to the amount, if any, by which his mvestment puts additional money into the pockets of his co-tenants. ${ }^{28}$ The cost of the improvement (we assume it was higher) is irrelevant to the amount of recovery, however judicious the expenditure may have seemed at the time. ${ }^{29}$ A related class of restitution plaintiffs, the "mistaken improvers" of property they do not own, likewise recover (if at all) for the value added by a mistaken improvement, not its cost. ${ }^{30}$

The same rules apply to payments made on behalf of another, whether voluntarily or by mistake. Where an action for contribution or indemnity arises out of payments made by the plaintiff in settlement of a third-party claim, a party to whom the defense of the claim has not been tendered is free to challenge the reasonableness of the settlement-to establish, in other words, that the true benefit to him was less than his share of the plaintiff's outlay. ${ }^{31}$ A claim in restitution by a surety against a principal is subject to the same restriction. ${ }^{32}$ One who mistakenly pays taxes assessed on a neighboring tract has a claim in restitution against the neighbor, but recovery is properly subject to the neighbor's defenses challenging the correctness of the assessment. ${ }^{33}$ More generally, any action brought by way of subrogation will be subject to all preexisting defenses to the original obligation, notwithstanding the fact that the plaintiff/subrogee may have discharged the original claim or lien at a hundred cents on the dollar. The effect is once again to limit liability to the benefit actually conferred on the defendant, even when the payment that entitles plaintiff to subrogation was very much larger.

washing machine left in storage by plaintiff); Vincent v. Lake Erie Transp. Co., 124 N.W. 221 (Minn. 1910) (unauthorized emergency mooring saves vessel at the cost of damage to plaintiff's dock). For the standard presentation of Vincent v. Lake Erie as a case of liability in restitution, rather than tort, see Robert E. Keeton, Conditional Fault in the Law of Torts, 72 HARV. L. Rev. 401, 410-12 (1959).

28. The benefit will typically be realized, in liquidated form, on the occasion of a partition by sale and subsequent accounting.

29. See 2 American Law of Property § 6.18, at 83-84 (A. James Casner ed., 1952).

30. See 2 PALMER, supra note $6, \S 10.9(\mathrm{e})$. The assumption in this context is that the cost of the improvement exceeds the value added. In the case of a profitable mistaken improvcment, plaintiff's recovery will be limited to his cost-not because plaintiff's cost is the measure of defendant's benefit, but because defendant's residual windfall, once plaintiff has been reimbursed for his mistaken expenditure, is no longer unjust enrichment at the expense of the plaintiff. Id.

31. Id. $\S 10.6$.

32. See Restatement of the Law of Suretyship $\$ 22 \mathrm{cmt}$. d \& illus. 4 (Tentative Draft No. 2 , 1993) (whereas "under the duty to reimburse, the secondary obligor is entitled to reimbursement for its reasonable outlay ... under the right of restitution recovery is limited to the [lesser] amount of the principal obligor's enrichment.").

33. Partipilo v. Hallman, 510 N.E.2d 8, 11-12 (1ll. App. Ct. 1987). 
Value may be reduced in the hands of a recipient because of idiosyncratic tastes or an idiosyncratic economic position. Because the value of a benefit to the recipient is the price he would pay in a voluntary transaction, recovery in restitution cannot exceed the price at which a recipient was contractually entitled to obtain the benefit in question. The leading illustration is Michigan Central Railroad Co. v. State, ${ }^{34}$ a case that arose upon the mistaken delivery to an Indiana state prison of a carload of coal consigned to another buyer. The coal was burned before the mistake was discovered. The railroad settled with the original consignee for the market value of the coal, $\$ 6.85$ per ton, and sued the State of Indiana in restitution for the value of the coal consumed. Unfortunately for the railroad, the prison's coal requirements were being provided under a long-term supply contract at a rate of $\$ 3.40$ per ton; thus, the benefit to the prison from burning anyone else's coal was limited to the saved expenditure at the contract rate. The court upheld an award for the railroad at $\$ 3.40$ per ton, rather than $\$ 6.85$, emphasizing that an action in restitution looks to the recovery of defendant's benefit, not to compensation for the plaintiff's injury. ${ }^{35}$

The reasoning of Michigan Central reveals the judicial error in Upton-on-Severn Rural District Council v. Powell, ${ }^{36}$ a famous case in which the plaintiff, a rural fire department, extinguished a fire in a barn that it believed, incorrectly, to lie within its district. The defendant landowner (who had no reason to suspect that the firefighters were not the right ones) was entitled to fire protection without charge from a neighboring fire department. The judgment of the Court of Appeal, requiring the landowner to pay for the mistakenly provided services, is certainly wrong, whether it is based on implied contract or restitution. If the theory is implied contractthe grounds on which the court appears to have proceeded ${ }^{37}$-the answer is that the defendant requested free services, and the plaintiff agreed to provide them. If the theory is restitution, the answer is that the plaintiff mistakenly bestowed services on someone to whom the services had little or no monetary value.

Mistaken providers of benefits to persons who do not value them at the going rate suffer what is essentially a casualty loss. It is as if the fire department had wasted its time putting out a bonfire; or as if the railroad, instead of misdelivering the coal to someone who valued it at half the market price, had accidentally dumped half of it into Lake Michigan.

34. 155 N.E. 50,50 (Ind. App. 1927).

35. Id. at 51 .

36. [1942] 1 All E.R. 220, 220 (C.A.).

37. "The real truth of the matter is that the appellant wanted the services of Upton; he asked for the services of Upton - that is the request he made-and Upton, in response to that request, provided those services." Id. at 221. 


\section{B. "Restitution" as a Contract Remedy}

Orthodox restitution limits recovery to the extent of the benefit to the recipient, but the casebooks and treatises include a sheaf of anomalous cases. These anomalies consist of instances in which a liability that was said to be in restitution was imposed on defendants who derived no economic benefit from the transactions in question. Not by coincidence, the phenomenon of "restitution without enrichment" occurs in a single setting: remedies that are restitutionary in form as a means of escape from a disrupted contractual exchange.

A list of such cases constitutes John Dawson's evidence for the existence of restitution without enrichment. The evidence, however, permits two inferences at least: either that restitution does not always require unjust enrichment, or that some sorts of liability that have been called "restitution" are in fact something else. ${ }^{38}$ What Dawson's examples actually reveal is that the forms of restitution-chiefly the action in quasi-contract (alias the "common counts")- have been employed to impose a contractual liability in a variety of settings im which orthodox contract remedies were formerly unavailable.

This conclusion is most obvious in those cases where what was once a gap in contract remedies has subsequently been filled; where a remedy that was first allowed in quasi-contract, because contract doctrine did not yet accommodate the problem, hás come to be available in contract directly. Dawson's leading examples are all cases of this kind. ${ }^{39}$

(1) The defendant repudiates a contract that the plaintiff is in the midst of performing. If the defendant's contractual obligation was to pay for performance on completion of the work, ordinary contract doctrine prior to the mid-nineteenth century gave the plaintiff no remedy for anticipatory repudiation. The defendant had committed no breach of contract, because

38. A third possibility is to treat these cases as part of restitution by insisting that the defendantscontrary to the ordinary meaning of the word-were in fact "benefitted" in some abstract sense. This third approach is essentially that adopted by Palmer. See, e.g., 1 PALMER, supra note $6, \S 1.8$ (defining "benefit" to mean either "an addition to the defendant's wealth" or "that a performance requested by the defendant has been rendered"). As we shall see, the controversial situations typically involve partial performance of a contract by the plaintiff (hence, "a performance requested by the defendant") that proves under the circumstances to be worthless; if a worthless serviee is to be regarded as a "benefit," the meaning of the word is very abstract indeed. Dawson was correct, in my view, in identifying his problem cases as instances of liability without enrichment; his error was to assume, on the basis of the forms of action employed, that they were instances of restitution.

39. Dawson's chosen examples of restitution without enrichment are the most dramatic ones: cases in which a defendant is found liable in restitution although he has arguably received nothing of economic value. See Dawson, supra note 9, at 577-85. Dawson omits a larger and more familiar set of cases, also involving contracts, that could equally well be classified as "restitution without enrichment." These cases employ restitution as an alternative remedy for a material breach, typically where the plaintiff has been performing at a loss. See Restatement (SeCOND) of Contracts $\$ 373$ (1979); 1 PALMER, supra note $6, \S 4.4$. The defendants in such cases have received economic benefit through the plaintiffs' partial performance; they are not enriched, howevcr, because they remain liable to pay for what they have received at the contract price. See Kull, supra note 7, at 1481-83. 
the precondition of defendant's obligation (tender of completed performance) had not yet occurred. Courts found a way to compensate plaintiffs, notwithstanding the absence of a breach, by allowing an action in quasicontract. Instead of awarding contract dainages, it was said, the law enforced the defendant's fictitious promise to pay the plaintiff for benefits conferred. But this "restitution" remedy was available even where the defendant had received nothing.

Thus in the leading case of Planche $v$. Colburn, ${ }^{40}$ a publisher was required to pay an author for his work in preparing the half-finished manuscript of a book. The book was neither completed nor published because the publisher abandoned the project (and repudiated his contract with the author) when the author was halfway through. Dawson is right to say that there is no measurable enrichment in such a case, but he fails to see that the remedy merely gave contract damages in disguise. After courts developed the doctrine of anticipatory repudiation, cases of this sort no longer presented a problem for contract law. If the facts of Planché $v$. Colburn were presented today, it would not occur to lawyers or judges that the plamtiff's reinedy required anything but enforcement of the contract. ${ }^{41}$

(2) The plaintiff seeks damages for loss incurred in reliance on the defendant's promise. Protection of the "reliance interest" against the consequences of broken promises has been an explicit feature of contract reinedies. only since the first Restatement of Contracts ${ }^{42}$ and Fuller and Perdue's The Reliance Interest in Contract Damages. ${ }^{43}$ Of course Fuller and Perdue's point was that the reliance interest, though not officially recognized, was in fact already protected. As in the case of anticipatory repudiation, one of the ways in which the courts managed to fill a perceived gap in contract reinedies was by allowing an action in quasi-contract for "benefit conferred." As in the former case, again, the fact that the recovery was available even for nonexistent "benefits" revealed that what the courts were really awarding was compensation for injury resulting from a broken promise. $^{44}$

40. 8 Bing. 14, 14-16, 131 Eng. Rep. 305, 305-06 (C.P. 1831).

41. See Restatement (SECOND) of Contracts $\$ 253$ (1979) (anticipatory repudiation "gives rise to a claim for damages for total breach" and "discharges the other party"s remaining duties to render performance").

42. See Restatement of Contracts $\S 90$ (1932).

43. See L.L. Fuller \& William R. Perdue, Jr., The Reliance Interest in Contract Damages (Parts 1 and 2), 46 Y ALE L.J. 52, 373 (1936/1937).

44. Onc of the significant consequences of recognizing the reliance interest in contract damages, as Fuller and Perdue observed, was precisely that it removed all these cases from the law of restitution, where they must inevitably be anomalous, and put them into contract, where they made sense:

[W] hen we examine the cases cited in the texts as cases of "restitution," we find much reason to suspect that in some of them the reliance interest has received protection under an alias... ....

In cases of the type under consideration, an expansion of the scope of restitution has been accomplished . . . in the first place, by substituting for "benefit" the notion of "bargained-for act".... 
In Kearns v. Andree, ${ }^{45}$ for example, the seller of a house redecorated it to suit an idiosyncratic buyer. After the buyer defaulted, the contract of sale was found to be unenforceable for indefiniteness. The decoration (which had reduced the value of the house) had to be done over to make the property salable once more. The seller was allowed to recover from the first buyer the wasted expense of the initial decoration. The real effect of such a judgment is to allow the plaintiff to recover reliance damages on the basis of promissory estoppel: the court itself described the case as one in which "the plaintiff seeks to recover the expense and loss which he has incurred in reliance upon the performance by the defendant of an [unenforceable] agreement."46 Because such a remedy was not yet officially recognized, however, the court employed the form of quasi-contract to yield a damage award, enforcing the defendant's fictitious promise to pay for a fictitious benefit conferred. Dawson points to Kearns $v$. Andree as an example of restitution without enrichment, but Fuller and Perdue had explained it more appropriately (forty-five years earlier) as a case awarding damages to protect the reliance interest in contract. ${ }^{47}$

(3) The plaintiff seeks damages that are speculative or difficult to calculate. At a time when contract doctrine was (in theory at least) more demanding about the proof of damages, quasi-contract offered an alternative route to compensation for plaintiffs who faced some peculiar obstacle in establishing the amount of their injury from the defendant's breach. Such a plaintiff might be a well-driller whose contract called for him to take nothing if he did not strike water, and who was ordered off the job before

The second extension of the notion of restitution ... is that where the plaintiff has performed a bargained-for act, his recovery is measured not by the defendant's enrichment, but by his own detriment. ...

....

... When the benefit received by the defendant has become as attenuated as it is in some of the cases cited, and when this benefit is "measured" by the plaintiff's detriment, can it be supposed that a desire to make the defendant disgorge is really a significant part of judicial motivation? When it becomes impossible to believe this, then the courts are actually protecting the reliance interest, in whatever form their intervention may be clothed.

Id. at $380,393-94$.

45. 139 A. 695,696 (Conn. 1928).

46. Id. at 697 .

47. Cases of contracts within the Statute of Frauds, in which the plaintiff's part performance of an unenforceable contract has conferred no tangible benefit on the defendant, present the same analytical choice. In Farash v. Sykes Datatronics, Inc., 452 N.E.2d 1245, 1246 (N.Y. 1983), a landlord sought to recover for expenditures incurred in renovating property for a tenant who never occupied the premises. Although the oral lease was held unenforceable, a majority of the New York Court of Appeals held that the plaintiff might recover in restitution. Id. at 1247. The court casually equated "reliance" and "restitution," suggesting that they differed "only in nomenclature," $i d$. at 1248, but the opinion made it embarrassingly clear that the court did not really understand the difference between the two theories of recovery. A more candid court would have acknowledged that it was enforcing the contract to the extent of reliance damages and therefore, inevitably, permitting an cnd-run around the Statute of Frauds. The case is discussed in Douglas Laycock, Modern American Remedies 586-90 (2d ed. 1994). On the same topic of avoiding the effects of the Statute of Frauds, see Fuller \& Perdue, supra note 43, at 38690 \& n.132; of. RESTATEMENT (SECOND) OF CONTRACTS $\S 139$ (1979) (approving promisee's action in reliance as grounds for enforcing a promise within the Statute of Frauds). 
completing the welli, ${ }^{48}$ or an architect whose fee was to be a percentage of construction costs on a project that was abandoned by the owner. ${ }^{49}$ Either could recover the "value of his services" in quasi-contract, though if the services consisted of a dry hole in the ground, or a set of plans for an abandoned building project, the defendants had received no tangible benefit froin partial performance. Dawson sees such results as further instances of restitution without enrichment. If the same plaintiffs were to come into court today, however, it is safe to predict that they would obtain identical recoveries under the heading of damages for breach. Relaxed standards for proof of contract damages (including the willingness to compensate reliance expenditure) have long since foreclosed any need for the quasi-contractual expedient.

In each of the examples considered so far, the remedy for breach-as ordinary doctrine has come to acknowledge-consists in the enforcement of the parties' agreement by an award of dainages, at least to the extent of the plaintiff's reliance. Because no lawyer today would seek a remedy in any of these circumstances by asserting a claim in restitution, it is difficult to see why we should any longer burden the law of restitution with what must inevitably be, as Dawson pointed out, a set of anomalous results. Cases such as these are not today regarded as imstances of restitution. Nor were they ever restitution, if we classify legal liabilities by function rather than form.

(4) The plaintiff seeks reimbursement for partial performance after a contract has been frustrated. If we move from cases in which the contract problem is default or repudiation to cases in which the problem is superveming impossibility or frustration, the law of restitution might at first appear to play a natural remedial role. Under such circumstances, in the conventional view, enforcement of the parties' bargain is beyond the power of the court (inasmuch as the terms of the agreeinent do not provide for the contingency), while performance up to the point of interruption may have conferred a benefit that would constitute unjust enrichment if not paid for. On closer examination, however, the case for restitution as a remedy for disrupted contractual performance disappears. This is because the necessary predicate of a recovery in restitution-discovery of a compensable benefit not paid for-is necessarily a function of contractual imterpretation. Once the agreement of the parties has been interpreted in a manner that will identify "unjust enrichment," a recovery in restitution is indistinguishable froin enforcement of the contract as interpreted.

Chandler v. Webster, ${ }^{50}$ one of the famous Coronation Cases, makes a classic example of the problem. The plaintiff paid the defendant $£ 100$ in advance for the hire of rooms from which to observe the coronation proces-

48. See, e.g., Thompson v. Brown, 76 N.W. 819 (Iowa 1898).

49. See, e.g., Stephen v. Camden \& Phila. Soap Co., 68 A. 69 (N.J. 1907).

50. [1904] 1 K.B. 493, 493-94 (C.A.). 
sion of King Edward VII. Before the date fixed for the celebration, the King fell ill, and the procession was canceled. What should happen to the $£ 100$ ? Although the parties had said nothing explicit about the risk of cancellation, a court on examining the transaction might presumably conclude (i) that the risk was implicitly assigned to the defendant, in other words that the contract imcluded an implied warranty; (ii) that the risk was implicitly assigned to the plaintiff, $m$ other words that the hiring of the rooms was unconditional; or (iii) that the parties' agreement failed to assign the risk one way or the other. Either of the first two interpretations permits enforcement of the contract, but on the third interpretation the contract has been frustrated.

If the contract has been frustrated, the court faces a further choice. It can either leave the money where it is, or order the defendant to return it. The conventional way to describe this alternative is to say that the court can either deny or allow an action in restitution. Yet, either course of action turns out to be a form of second-order contract interpretation. A rule that demies restitution and leaves losses to "lie where they fall" (the common shorthand for what came to be known as "the rule of Chandler v. Webster") rests on a presumption that the risks of all contingencies, foreseeable or otherwise, are necessarily allocated by the terms of a contract. The risk of any contingency as to which the contract is silent is therefore deemed to be left by the parties wherever circumstances may ultimately place it; it is tacitly assigned, in other words, to the party adversely affected. ${ }^{51}$ On the facts of Chandler, this logic yields a presumption that, because nothing was said about a refund of the deposit, the risk of cancellation was assigned to the plaintiff. $^{52}$ If the risk was assigned to the plaintiff, moreover, the defendant is not unjustly enriched if he retains the $£ 100$ deposit. Thus it becomes impossible to decide the issue of restitution on a priori grounds-by asking whether there is unjust enrichment on these facts-without first identifying, or imposing as a default rule, a contractual risk allocation. Restitution and enforcement of the contract turn out to be one and the same.

Suppose the court in Chandler were to allow a claim in restitution. The usual explanation would be that the defendant would be unjustly enriched if he kept the money. But the perception of "injustice" in this

51. See Andrew Kull, Mistake, Frustration, and the Windfall Principle of Contract Remedies, 43 Hastings L.J. 1, 22-31 (1991) (discussing the rule in Chandler v. Webster and its relation to the contractual allocation of loss from unforeseen contingencies).

52. Judicial refusal to intervene in these circumstances actually works a more complex assignment. Money paid in advance will not be returned; money promised but not yet due by the terms of the agreement, at the point when performance is interrupted, need not be paid. See Chandler v. Webster, [1904] 1 K.B. 493, 497 (C.A.); Krell v. Henry, [1903] 2 K.B. 740, 754 (C.A.). Strictly, therefore, the risk of cancellation is assigned to the paying party to the extent the price has been paid and to the performing party to the extent the price is not yet due. In a judicial regime of nonintervention, payment terms thus afford contracting parties a means of allocating the incidence of loss from unforeseeable frustration of the transaction. Common experience suggests that payment terms are (to some extent at least) actually employed in this manner. See Kull, supra note 51, at 50-51. 
situation depends on a converse interpretation of the parties' agreement: a determination that, absent an express agreement to the contrary, the parties have assigned the risk of cancellation to the defendant. A decision employing the language of unjust enrichment to allow restitution on the facts of Chandler is therefore indistinguishable, in logic and effect, from a decision imposing some form of implied warranty as a default rule to govern contracts of this type. ${ }^{53}$

The reasoning is inevitably circular, because in trying to assess the consequences of imterrupted contractual performance, we have no standard by which to judge enrichment or its absence other than the terms of the parties' agreement. Because we view the parties' agreement as the proper measure of value between them, a rationalized (enrichment-based) law of restitution has no independent role as a remedy for disputes arising out of the breach or frustration of a valid contract. ${ }^{54}$

The real function of "restitution" in the context of interrupted contracts is even clearer where a partial performance has been destroyed by a supervening casualty that leaves behind nothing but losses. In inost American jurisdictions, a builder employed to do part of the work of constructing a new building, or to make repairs or improvements to an existing one, has a claim in restitution for the value of his labor and materials when the struc-

53. In short, it is impossible to employ "restitution" to assign losses from frustrated contracts without, as an initial matter, making an assignment of the relevant risks; once the risks have been assigned, the "restitution" that follows is in effect an enforcement of the contract that the court has written for the parties. How this works in practice may be seen in Fibrosa Spolka Akcyjna v. Fairbairn Lawson Combe Barbour, Ltd., [1943] App. Cas. 32, 33-34 (H.L. 1942). The plaintiff, a Polish textile company, ordered "certain flax-hackling machines" in July 1939 from the defendant, an English manufacturer. The equipment was to be delivered "c.i.f. Gdynia." Plaintiff paid a $£ 1,000$ deposit. Six weeks later, Germany invaded Poland (and occupied Gdynia); Britain declared war on Germany. Performance of the contract was henceforth both impossible and illegal. Plaintiff asked for the return of its deposit; defendant refused, on the grounds that considerable work had already been done on the machines. Reversing the lower courts, the House of Lords held that the plaintiff might recover $£ 1,000$ in restitution. $I d$. at 50 . The decision was wrong, and its rationale seriously deficient. Reimbursement of the deposit is justified in restitution only if the defendant would be unjustly enriched by retaining the money. But the answer to the question of enrichment necessarily depends on how the relevant risks were assigned by the parties. On the facts of Fibrosa, this critical question of risk allocation was wrongly decided. Given that the parties were bargaining against the backdrop of imminent war and of existing English law, which (before Fibrosa) clearly denied restitution in such circumstances, see id. at 43 , it is reasonable to conclude that they assigned to the buyer the (highly foreseeable) risk of loss from wartime frustration, to the extent the buyer agreed to make payments in advance of delivery. See Kull, supra note 51, at 34-35, 49-53 (discussing the "displaced private alloeation" of frustration losses in Fibrosa and similar cases).

54. The attempt to identify unjust enrichment in a contractual context inevitably dissolves into contract interpretation (I am indebted to Douglas Laycock for this turn of phrase) because we have no standard by which to measure either justice or injustice in a contractual exchange apart from the parties' agreement, actual or imputed. By contrast, where the defendant has committed a profitable tort, the reason that unjust enrichment does not similarly dissolve into tort law is that the parties are in this sense strangers: they have not fixed by agreement the rules by which each shall account to the other for beneflts derived from their interaction. Justice between wrongdoer and victim is therefore defined not by contract but by external social standards, and these standards can be framed with equal logic in terms either of defendant's gain (restitution) or plaintiff's loss (tort). 
ture on which he is working is destroyed by casualty before the work is completed. ${ }^{55}$ By contrast, where the builder has undertaken full responsibility for construction of a new building, destruction by casualty prior to completion merely obligates him to start over, with no claim in restitution for "benefit conferred" up to that point. ${ }^{56}$ The distinction between the two basic situations, like the further distinctions drawn by the cases to determine the precise amount of "benefit" conferred by some abortive improvements and not others, would be indefensible if the results in these cases had anything to do with restitution for benefits conferred. What the courts did here, in reality, was to establish default rules for the allocation of casualty losses in certain recurring contractual situations. (If the allocations were justifiable in terms of such practicalities as insurable interest, they may well have been appropriate.) The decisions were structured in quasi-contract, despite the extreme artificiality of the "benefits" confcrred, because judges were unwilling to acknowledge they were inaking contracts for the parties.

In summary, then, the cases advanced as instances of "restitution without enrichment" pose no obstacle to a rationalizcd restitution, because they prove on examination to be inore appropriately classified as instances of contract liability. Pursued to its logical conclusion, the same reasoning about the contractual allocation of risks and duties removes most contract disputes altogether from the scope of enrichment-based restitution, because we can make no determination about unjust enrichment between the parties to a contract that does not depend on the terms of their agreement. This conclusion is an important one, because the traditional classification of topics within "the law of restitution"-by including every instance of a liability originally pleaded in quasi-contract-has incorporated a wide range of contract disputes that find no place in a rationalized conception of the subject.

\section{The Turkish Bathhouse}

Dawson asserted that the standard work of restitution lay in "the unwinding of contracts, actual or supposed." concerned-as we have seen in the examples considered so far-an independent role for restitution is properly displaced by the interpretation and enforceinent of the parties' agreenent. In the rare cases of "supposed" contracts, however, the situation is very differcnt. Questions of enrichment cannot be determined by reference to the parties' agreement where the agreement does not exist. Dawson's ultimate example of "restitution without enrichment" is Vickery $v$. Ritchie, ${ }^{58}$ the wonderful case of the Turkish

55. See, e.g., Butterfield v. Byron, 27 N.E. 667, 669 (Mass. 1891).

56. See, e.g., Superintendent of Trenton v. Bennett, 27 N.J.L. 513, 519-20 (1859) (partly completed schoolhouse leveled by tomado).

57. Dawson, supra note 9, at 577.

58. 88 N.E. 835 (Mass. 1909). 
Bathhouse. Vickery involved restitution, not contract, and Dawson rightly points out that it imposed liability without enrichment. The problem is that Vickery was wrongly decided.

The plaintiff in Vickery was a builder who made inefficient improvements to real estate in the reasonable belief that he had a contract with the owner when in fact he did not. Negotiations between builder and owner had been carried out by a fraudulent intermediary, an architect, who evidently perceived that in the ordinary course of events the bathhouse project was not going to be built. To avert this natural outcome (and obtain his commission), the architect invited the builder to sign a contract on which the price was stated to be $\$ 33,721$, while on the copy presented to the owner the price for the same construction was set at $\$ 23,200$. The builder completed performance and discovered he had no contract with the owner. When the owner declined to pay inore than the $\$ 23,200$ he had understood to be the price of the work, the builder sued in restitution for the difference. A referee appointed by the court appraised the value of the builder's work and materials at $\$ 33,500$. On the other hand, the measurable benefit to the owner from the work of construction - the increased value of the real prop-. erty attributable to the improvement-was appraised at $\$ 22,000 .{ }^{59}$

The court in Vickery held that the builder was entitled to $\$ 33,500$ for his work. ${ }^{60}$ Liability of the owner for this amount was ostensibly im restitution, though the cognizable benefit to the owner was clearly no more than $\$ 23,200{ }^{61}$ Judged by the unjust enrichment axiom, the decision is indefensible. With respect to each dollar spent by the builder after the first $\$ 23,200$, the relation of the builder to the owner was merely that of a particularly unfortunate mistaken improver-one who not only constructs improvements on a neighbor's land without a promise of payment, but who (like a mistaken well-driller who fails to reach water) spends money on a project that adds no value to his neighbor's property.

Restitution without enrichment this assuredly is. Dawson goes further and defends the result as equitable, which it is not. ${ }^{62}$

59. Id. at 835 .

60. Id. at 837 .

61. The owner's subjective valuation of the improvement is in a sense unknowable, but there is nothing to justify the inference that it was significantly higher than the amount he agreed to pay as a willing buyer. Recovery of $\$ 23,200$ (the owner's "contract price") rather than $\$ 22,000$ (the appraised value of the improvement) is justifiable in restitution because the higher figure captures the owner's voluntary appraisal of the benefit to him. See Restatement of Restitution $\S 155(2)$ (1936).

62. Dawson defends the result in Vickery by pointing to the fact that the owner had undertaken to pay for the very work that was done, argning that the owner "should pay the value of the human and material resources that had been expended in accordance with his request." Dawson, supra note 9 , at 596. The statement misrepresents the substance of the owner's request, which was for an expenditure of resources that would be fully compensated by his payment of $\$ 23,200$. Suppose Farmer Jones meets a fast-talking architect who tells him about a building contractor so desperate for business that he will construct a new bam, absolutely free, somewhere in the neighborhood, just to advertise the quality of his work. Jones urges that the specimen barn be built in his own pasture. The architect shows Builder Smith a contract, bearing the forged signature of Jones, promising to pay $\$ 10,000$ for a new barn. Smith 
The owner in Vickery was not in the position of someone who receives a valuable benefit but makes unprofitable use of it: someone, for instance, who receives $\$ 100$ by mistake and invests it in shares that immediately lose half their value. (A restitution defendant in that position is liable for $\$ 100$, because the investment transaction is considered to have been for his own account. ${ }^{63}$ ) On the contrary, the owner's expressed willingness to pay for the benefit in question - the one factor that kept the builder from being simply a mistaken improver-was conditioned on the builder's apparent undertaking to erect the bathhouse for $\$ 23,200$. Like a railroad delivering coal to someone who could have obtained it for half the market price, the builder suffered what was essentially a casualty loss in conferring (by mistake) a $\$ 33,500$ structure on someone who valued it at $\$ 23,200$.

Perhaps Vickery is ultimately a decision that simply reassigns a loss between the parties, applying a principle like that of "sharing" in response to a "contractual accident." 64 Sharing or loss-shifting makes a far more convincing explanation of the result in the case than its ostensible rationale in terms of unjust enrichment. Sharing is not restitution, however, and the use of restitution as a pretext in such instances merely obscures the rule that is actually being applied. ${ }^{65}$

\section{II}

\section{RESTITUTION AS RESTORATION}

"Restitution," im plain English, means "restoration." 66 The dictionary definition helps to explain the lack of consensus regarding the content of

builds a barn at a cost of $\$ 10,000$. The barn adds nothing to the value of Jones's land. Does it follow that Jones "should pay the value of the human and material resourccs expended in accordance with his request"?

63. Thus it is no defense, in an action to recover in restitution for services performed under an oral contract of employment (unenforceable because of the Statute of Frauds), to prove that the plaintiffs services generated no profit for the defendant, the plaintiff having been employed in a losing venture. See, e.g., Fabian v. Wasatch Orchard Co., 125 P. 860, 862 (Utah 1912).

64. "Sharing applies where there are no rights to respect. It is the principle that would apply if a group of us were to land together on some new planet. It is peculiarly appropriate to filling the gaps in agreements, to picking up after contractual accidents." Charles Fried, Contract as Promise 71 (1981) (footnote omitted).

65. For a comparable instance of restitution as pretext, see Campbell v. Tennessee Valley Auth. 421 F.2d 293 (5th Cir. 1969). Here the plaintiff provided goods and services to a govcrnment agency (microfilming of journals for the TVA library) without having obtained a valid contract for the work. Recovery, therefore, was technically in restitution. The court affirmed a judgment for $\$ 30,000$ (the amount allegedly promised to the plaintiff pursuant to an invalid oral agreement), in the face of evidence establishing that the benefit to the TVA from the plaintiff's efforts was somewhere between $\$ 10,000$ (the price of the job on the open market) and nothing (since it was possible that the agency did not really want the work done). Id. at 294,297 . The case is one, like Vickery, in which a court employs sham restitution to attain an end it does not feel it can acknowledge: in this instance, to enforce an ultra vires agreement against a government agency when the applicable statutes prohibit enforcement.

66. Judges are more apt to recall this natural meaning of the word "restitution" than its artificial connotation of liability for unjust enrichment. See, e.g. Hughey v. United States, 495 U.S. 411,416 (1990) ("the ordinary meaning of the word 'restitution' is restoring someone to a position he occupied before a particular event"). 
restitution law, but it is an error to argue from the dictionary in attempting to define "the law of restitution." This is because the word "restitution," as a name for a body of law, is essentially a modern coinage: it is the word chosen by Warren Seavey and Austin Scott in 1936 to describe those rights and remedies whose unified treatment they inaugurated in the Restatement of Restitution. Because the law described in the Restatement is the law of unjust enrichment, the naine "restitution" was an unfortunate choice, and Seavey, at least, appears eventually to have thought better of it. ${ }^{67}$ But the damage had already been done.

The problematical character of the name "restitution" was recognized at the outset. Introducing the Restatement to a skeptical British audience, Seavey and Scott addressed first their choice of a name for the new subject:

Although it is a rule of the [American Law] Institute that no new word should be coined, it is consistent with its practices to use an old word with either a more precise or a more generalized meaning. With this in mind, the word 'restitution' was chosen, a word which has a connotation of the right to recover back something which one once had. ${ }^{68}$

But why would the authors have favored that connotation? The same article made it perfectly clear that unjust enrichment, and not "the right to recover back soinething which one once had," was at the center of the new Restatement's subject matter. The authors pointed to "one unitary principle which heretofore has not had general recognition," calling it a "third postulate" 70 of civil liability, on a level with liability in contract and liability in tort:

This third postulate, which underlies the rules assembled in the Restatement under the heading 'Restitution,' can be expressed thus:

67. "Restitution is the equitable principle by which one who has been enriched at the expense of another, whether by mistake, or otherwise, is under a duty to return what he has received or its value to the other. Perhaps unjust enrichment would be a better term." Warren A. Seavey, Problems in Restitution, 7 OKLA. L. Rev. 257, 257 (1954). Shortly after its publication, Philip Mechem had observed that the ALl's new work was "called the Restatement of Restitution but [was] in fact a restatement of a law of unjust enrichment." Mechem, supra note 5, at 188 . The name ultimately chosen for the Restatement was apparently the result of a last-minute editorial change. Numerous preliminary and tentative drafts prepared by Seavey and Scott from 1934 to 1936 all bore the title Restatement of Restitution and Unjust Enrichment, as did the Proposed Final Draft submitted to the Annual Meeting of the ALI in May 1936. Discussion of the project on that occasion evoked repeated objections that certain sections were contradicted by the case law; that others were difficult to understand; and that nobody had had an adequate chance to read the draft beforehand. The meeting nevertheless voted to approve the official Restatement of the Law of Restitution and Unjust Enrichment, but subject to such revisions, involving "matters of style and changes in the interest of clarity," as the Reporters and the Executive Committee might thereafter choose to make. See 13 A.L.I. Proc. 329-32 (1936). The decision to change the name was made in committee, presumably in the interest of brevity, after the text had been officially adopted.

68. Warren A. Seavey \& Austin W. Scott, Restitution, 54 LAW Q. Rev. 29, 29 (1938).

69. Id. at 31 .

70. Id. at 32 . 
A person has a right to have restored to him a benefit gained at his expense by another, if the retention of the benefit by the other would be unjust. The law protects this right by granting restitution of the benefit which otherwise would, im most cases, unjustly enrich the recipient. $^{71}$

The language employed here is noteworthy, because it points to the source of confusion. When they spoke of a benefit's being "restored," or of the law's "granting restitution of the benefit," Seavey and Scott evidently had in mind the circumstances of the typical unjust enrichment claim. Restitution can be seen as an aspect of the legal protection of property, and many instances of what the law characterizes as unjust enrichment might be described by saying that the defendant has received property of the plaintiff by means of a transfer that was legally ineffective to convey ownership. This is the case, for example, not only where defendant's unjust enrichment arises from an act of outright conversion, but also where the claim to restitution is based on a mistaken payment. In these and many other circumstances, restitution's ordinary mode of operation is to restore to the plaintiff what was formerly his property, or its value.

But while the remedy for defendant's unjust enrichment will often involve restoring something to the plamtiff, remedies that consist in restoration are by no means coextensive with liability for unjust enrichment. The remedy for important instances of unjust enrichment typically involves paymg the plamtiff money that was not previously his, as where an infringer is liable for profits exceeding the value of anything the plaintiff lost. ${ }^{72}$ Conversely, plaintiff may be entitled to restoration of property or its value from a defendant who was not enriched by its receipt; such are the rights of owners against good-faith purchasers of stolen property. There is thus a substantial but imperfect (and therefore misleading) coincidence between unjust enrichment and restoration, in that both the liability and the remedy may attach to the same set of facts. The logical connection between them, however, is no greater than that between restoration and liability for breach of contract, or between restoration and liability for tort.

Seavey and Scott's choice of the name "restitution" to designate the law of unjust enrichment was in fact a serious blunder. "Restitution" signifies legal liability based on unjust enrichment only when the word is used as a term of art that (in American practice) is becoming increasingly unfamiliar; the ordinary lawyer is actually more likely to associate the term "restitution" with criminal sanctions. Conversely, the word's ordinary

71. Id.

72. Cases involving the recovery of profits earned through the defendant's use of property misappropriated from the plaintiff have everything to do with unjust enrichment and nothing to do with specific restitution. As Douglas Laycock remarks, in such cases "we are not restoring anything that plaintiff once had or ever would have had." Laycock, supra note 10, at 1281. 
connotations of restoration and giving back describe remedies that bear no necessary relation to enrichment-based liability.

Those commentators who describe restitution as restoration do not, in fact, argue that restoration and unjust enrichment are logically or functionally linked. On the contrary, they argue that the law of restitution includes a restoration component not dependent on defendants' unjust enrichment. Observing that the word "restitution" means both "recovery based on and measured by unjust enrichment" and "restoration in kind of a specific thing," Douglas Laycock inaintams that "[b]oth usages are part of any complete definition of restitution."73 Specific restitution is "part of the core concept of restitution" and is "conceptually equal to the avoidance of unjust enrichment." " Other writers, emphasizing a somewhat different sense of "restoration," have argued that the essence of restitution in a contractual context consists not in the identification of unjust enrichment but in the restoration to the plamtiff of his performance or its value-thus restoring the plaintiff to the status quo ante. ${ }^{75}$

The relation between restitution and restoration requires examination for two reasons. The first is simply a matter of organizational clarity. If the link between enrichment-based restitution and the restoration remedies is as fortuitous as I have suggested, then it is a serious analytical error to try to lump them together. A restoration remedy such as replevin has precisely the same relation to restitution (meaning, to liability based on unjust enrichment) that it has to contract or to tort. The second reason goes beyond mere classification to touch on the substance of entitlements and liabilities. "Specific restitution" and "restoration of the status quo ante" are expressions that describe remedial outcomes. The simplest way to explain such outcomes is to describe them as giving effect to preexisting property entitlements. Do they do anything besides? If a claim to "specific restitution" or "restoration" has legal content of its own, then these remedial techmiques are more than merely remedies, and it will be important to understand what additional rights and obligations they impose. If, on the other hand, the restorative remedies are simply devices for putting property back into the hands of its owners, then analytical econony (Occam's Razor) suggests that it is inappropriate to identify either "specific restitution" or "restoration to the status quo ante" as a legal principle independent of ordinary property rights.

\section{A. Specific Restitution as a Concept}

Restitution in Douglas Laycock's description is a body of law that comprises two "strands," unjust enrichment and specific restitution, each

\footnotetext{
73. $I d$. at 1279 .

74. Id. at 1280.

75. See infra note 89.
} 
"conceptually equal" to the other. ${ }^{76}$ Such an account of the subject, on the face of it, presents us with a peculiar combination of an apple and an orange. Because unjust enrichment is a source of liability, while specific restitution is a remedy, it is difficult to see them as "conceptually equal." Unjust enrichment, as a concept, resembles contract and tort; specific restitution, as a concept, resembles money damages. Nor is there any thematic relation between specific restitution and enrichment-based liability that makes it appropriate to treat them together.

Specific restitution will admittedly be an especially effective remedy for certain instances of unjust enrichment. If the coal delivered by mistake in Michigan Central had not been consumed, specific restitution of the coal would have avoided the loss from a value-reducing transfer. ${ }^{77}$ In the same way, however, the restoration of specific property will sometimes be the ideal remedy for tort (defendant converts heirloom) or breach of contract (plaintiff rescinds after delivery of heirloom). Actually, the remedy for all three types of liability is far more likely to be a monetary payment. The choice between specific and substitutionary relief is in each case a question of remedial efficiency-how close the remedy comes to yielding the plaintiff's legal entitlement, and at what administrative cost-not of the underlying basis of liability.

Laycoek does not assert that there is any particular congruence between enrichment-based liability and the restoration remedies; indeed, he notes that "[n]either usage of the term [restitution] subsumes the other." And yet his definition of the subject keeps the two meanings tightly yoked. "Both usages are part of any complete definition of restitution," to Laycock, and it would be "wrong to disclaim" that part of the definition not referable to unjust enrichment. ${ }^{80}$ It seems odd, however, to perpetuate a heading of doctrine whose "core concept" comprises two "strands" whose primary connection is that one equivocal noun may be used to name them both.

Is there in fact any respect in which the two meamings of "restitution" bear more than a coincidental relation to each other? Laycock identifies just one context in which "a claim to specific restitution adds something to a claim of unjust enrichment."81 Here he points to the law of tracing, the ability to follow an asset through successive forms that is a distinctive feature of restitution claims in certain contexts. But while the tracing rules give important advantages to a claimant who can establish a link between "his" property and some specific asset in the hands of the defendant, it is

76. Laycock, supra note 10, at $1280,1293$.

77. See supra text accompanying notes 34-35.

78. Laycock, supra note 10 , at 1280.

79. Id. at 1279.

80. Id. at 1280 .

81. Id. 
not clear that tracing in the restitution context is anything more than a tool for identifying unjust enrichment.

There are two basic tracing scenarios in restitution, and neither of thein, strictly speaking, has anything to do with specific restitution. The first involves a simple dispute between the plaintiff and the wrongdoing defendant. Here tracing allows a plaintiff to follow misappropriated property into its appreciated product. If the plaintiff can prove that $\$ 10$ einbezzled from him was used by defendant to buy property now worth $\$ 100$, plaintiff has a claim to the property. Restitution concludes that the defendant has been unjustly enriched in the amount of $\$ 100$, not $\$ 10$, but the remedy is hardly specific restitution; on the contrary, the plaintiff recovers property worth ten times what he lost.

In the second tracing scenario, where the real contest is between rival creditors, the tracing rules are more appropriately seen as a rough guide to unjust enrichment than as a means of effecting specific restitution. Imagine two claimants, each of whom can prove that he was defrauded of $\$ 100$ many years ago by someone who is now an insolvent debtor. Clainnant $A$ can trace his $\$ 100$ : it was used to buy a gold watch, which is found among the debtor's assets. Claimant $B$ 's $\$ 100$ is untraceable. It is likely that Clainant $A$ will get the watch and that Claimant $B$ will join the ranks of the general creditors. ${ }^{82}$ Laycock suggests that specific restitution here yields a reinedy that enrichment-based liability cannot explain.

Yet if we bear in mind that the real dispute in such a case is between the restitution clainnant and the other creditors, ${ }^{83}$ tracing can be understood as a rule of thumb for resolving certain intractable problems of but-for causation bearing on the question of unjust enrichment. Clainant $A$, who can point to specific property (the watch) in the hands of the debtor, inakes a relatively persuasive case that the debtor's net assets have been augmented to the extent of the misappropriation. Giving a $\$ 100$ priority to $A$ prevents the unjust enrichment of the rival creditors at $A$ 's expense, if we agree that the creditors should not be looking to the fruits of the debtor's fraud for the satisfaction of their clains. Claimant $B$, by contrast, who is unable to trace any proceeds of his $\$ 100$, finds it harder to dispel the natural objection of

82. This is clearly the result in restitution (via the remedy of constructive trust). The viability of restitution in a bankruptcy context has been questioned by some modern judges who fail to grasp the legal principles involved: a notable recent example is In re Omegas Group, Inc., 16 F.3d 1443, 1452 (6th Cir. 1994) ("Constructive trusts are anathema to the equities of bankruptcy since they take from the estate, and thus directly from competing creditors, not from the offending debtor."). Such a statement discounts a century of judicial authority to the contrary: see, e.g., American Sugar-Refining Co. v. Fancher, 40 N.E. 206 (N.Y. 1895); In re Berry, 147 F. 208 (2d Cir. 1906); In re North American Coin \& Currency, Ltd., 767 F.2d 1573, 1576 (9th Cir. 1985) ("creditors should not benefit from fraud at the expense of those who have been defrauded"). It also misstates the equitable principle at stake, whichconsistent with the rest of bankruptcy - is to determine priorities among claimants not similarly situated.

83. See Steven Walt \& Emily L. Sherwin, Contribution Arguments in Commercial Law, 42 EмORY L.J. 897, 901-05 (1993) (discussing effect of constructive trust in assigning priorities among creditors). 
rival creditors: namely, that the misappropriated funds have probably been dissipated long since, producing no lasting augmentation of assets and no enrichment to them. ${ }^{84}$

Liability and remedy in this setting are functionally identical, moreover, without regard to the nature of the asset in which the restitution plaintiff claims priority. The plaintiff who discovers among the defendant's assets the very thing that was "his" (a stolen watch, or currency kept in a mattress) has no need of tracing to assert a prior claim. The plaintiff who, with the aid of tracing, can identify proceeds, or proceeds of proceeds, obtains the same priority, despite the fact that "his" watch or currency have long since come into other hands. The first of the two claimants obtains what is incidentally specific restitution, but the second obtains what is effectively the saine reinedy: restitution premised on the unjust enrichment of rival creditors. What the two situations have in common is the palpable augmentation of the debtor's assets, not the restoration of specific property.

The concept of liability with which specifie restitution is in fact consistently associated is not unjust enrichment; it is the idea that the law awards ownership to the clainant with superior title. That central rule of property operates to prevent unjust enrichment, but only in the weakest and most general sense. Every reinedy. for a profitable wrong prevents the unjust enrichment of the defendant, at least if the alternative is no remedy at all. ${ }^{85}$ Specific restitution gives effect to preexisting property entitlennents (and in this weak sense prevents unjust enrichment in some cases); but it is

84. The hypothesis that traceability serves as a rough guide to the lasting (nondissipated) augmentation of the debtor's assets also helps to explain the rule of "lowest intermediate balancc." A claimant who seeks to traee money through a commingled fund-for example, a bank account in which a wrongdoer has deposited both the claimant's money and his own-is assisted in identifying "his" money by some favorable prcsumptions about whose money the wrongdoer was spending; but the law will not presume that the funds of the claimant, once dissipated, are restored by subsequent deposits. The result is that the claimant cannot identify as "his" any portion of a commingled fund greater than its lowest balance between the time the claimant's money is deposited and the time the claim is asserted. See Connecticut Gen. Life. Ins. Co. v. Universal lns. Co., 838 F.2d 612, 619-20 (1st Cir. 1988) (explaining the mechanics of the lowest intermediate balance rule). Like the rules of traceability in general, the lowest intermediate balance test thus distinguishes the net augmentation of the debtor's assets from the gross contribution made (involuntarily) by the claimant. Because the claimant's rights vis-à-vis other creditors depend on a showing that they are in some sense being paid with the claimant's money, his claim in restitution is good only to the extent that "his" money has not already been spent.

85. A seller who accepted plaintiff's $\$ 100$ payment in advance and then failed to make the promised exchange of goods worth $\$ 100$, like a thief who sold for $\$ 100$ property of the plaintiff worth $\$ 100$, would be unjustly enriched if he faced no legal liability for his misdeed. There is aecordingly a sense in which ordinary contract damages (in the first case) and ordinary tort damages (in the second case) might logically be described as liability imposed to prevent the unjust enriehment of the defendant at the expense of the plaintiff. In all such instances, however-where the injury to the plaintiff from the defendant's wrongdoing equals or exceeds the benefit to the defendant-both established usage and analytical convenience dietate that liability be primarily explained in terms of the harm, not the benefit. By contrast, unjust enrichment becomes visible as the basis of liability either where the defendant has breached no independent duty to the plaintiff, or where the benefit to the defendant from the defendant's wrong exceeds the injury to the plaintiff. See infra text aceompanying note 98 . 
difficult to see either that it does anything more, or that it does this much in any distinctive way.

At every point, in fact, where specific restitution serves to enforce a legal liability based on unjust enrichment, the same result could be (and more frequently will be) attained by an award of money damages. A remedy in specie may offer important advantages in a particular case, but these advantages relate to the efficiency of the remedy, not to the underlying basis of liability. ${ }^{86}$ The relation between unjust enrichment and payment of money is just as close as the relation between unjust enrichment and specific restitution; yet it would not occur to us to describe payment of money as part of the core concept of restitution, nor indeed to regard it as a legal principle at all.

\section{B. Status Quo Ante as a Contract Remedy}

When the Restatement of Restitution was adopted in 1936, there was only one context in which the word "restitution" was in common use as a legal term. The remedy of rescission, available for certain breaches of contract, was frequently called "rescission and restitution." 87 This was straightforward descriptive terminology, because rescission of a contract, most of the time, is inevitably a two-step process.

For example, if a buyer pays the price of goods in advance, and the seller does nothing, the buyer has a choice between enforcement of the contract, on the one hand (whether by specific performance or damages), and rescission on the other. If the buyer elects to rescind, he is entitled to recover the price paid. Or suppose a farmer delivers a horse in exchange for his neighbor's promise to deliver a cow a week later. If the neighbor defaults, the farmer has the same choice between enforcement and avoidance. Rescission entitles the farmer to recover his horse, in preference either to the cow or to the cow's value. ${ }^{88}$

The circumstances of these simple cases suggest that the "restitution" part of "rescission and restitution" is merely a description of the end result, not a reference to the basis of liability. The basic remedial choice afforded by contract law is most simply described as one between enforcement and avoidance. If the contract remains wholly executory at the moment of

86. The cardinal advantage of a remedy in specie, realizable in some circumstances and not others, is that it gives the plaintiff "the very thing he lost if that is what he wants," thereby avoiding the costs of third-party valuation necessarily attendant on any award of money damages. See Douglas LAYcock, THe DeATH OF THE IRREPARABLE INJURY RULE 13 (I991).

87. For the established contemporary usage, see 3 SAMuer Williston, The LAw of Contracts ch. 40 (1920). The term "Trescission and restitution" has been carried forward in subsequent editions of Williston's treatise. See 12 Samuel Williston, a Treatise on the Law of Contracts ch. 44 (Walter H.E. Jaeger ed., 3d ed. 1970).

88. For a discussion of these and other paradigmatic cases in which the law allows rescission as an alternative to enforcement, with citations to authorities and a hypothesis to explain the availability of rescission in some cases and not others, see Kull, supra note 7, at 1492-95, 1499-1505, 1513-16. 
default, rescission by the plaintiff is the end of the matter: the plaintiff is at once restored to the status quo ante, and no other form of "restitution" is necessary. By contrast, where the plaintiff elects to rescind after part performance on one or both sides, avoidance of the contract leaves a partly completed exchange without a legal basis. The buyer's money is in the seller's hands; the farmer's horse is in the neighbor's barn. Unwinding the rescinded transaction requires that property already delivered be restored to its owners. Particular techniques of restoration have their own proper names: replevin for the horse, quasi-contract (money had and received) for the money. As in the case of specific restitution, however, the legal principle involved appears to be no more than an application of the central rule of property.

Might there be, in some other cases of rescission, an additional principle at work, over and above the elementary proposition that the law protects paramount title? Writers on contract have often asserted that where restitution is employed as a remedy for default, its function is not to prevent the unjust enrichment of the defendant but to vindicate the plaintiff's right to be restored to the status quo ante. ${ }^{89}$ Note that, with this change of emphasis, the claim to restitution becomes an affirmative entitlement on the part of the plaintiff-the "restoration interest"-rather than simply the mechanical consequence of (i) avoiding the contract while (ii) honoring ordinary property claims. Still we need to ask whether the restoration interest has some discernible legal content that makes it more than a specialized label for property rights; and assuming it does, whether there is any reason, apart from the coimcidence of the name, to associate this restoration interest with the topic of liability for unjust enrichment.

The answer to the first question evidently turns on a much-disputed question of contract remedies. Restoration to the status quo ante may do more than restore the plaintiff to possession of his property. It will yield a positive addition to the plaintiff's assets if the remedy allows the plaintiff to avoid an exchange that further information, such as a shift in costs or market prices, has revealed as unfavorable. "Rescission and restitution" is merely a less-expensive substitute for enforcement in some cases, as where

89. See 5 arthur L. Corbin, Corbin on Contracts $\$ 1107$, at 573 (1964) (purpose of restitution "is to require the wrongdoer to restore what he has received and thus ... to put the injured party in as good a position as that occupied by him before the contract was made"); Eric G. Andersen, The Restoration Interest and Damages for Breach of Contract, $53 \mathrm{MD}$. L. REv. 1, 3-4, 32-36 (1994) (summarizing the author's contention that the function of restitution as a contract remedy is to protect "the restoration interest, which returns the breach victim to the economic position he occupied before the contract was made"); Dawson, supra note 9, at 621 (in the context of "disrupted exchange agreements," where restitution "renders its most neccssary and useful service," its function is "to throw the transaction into reverse by giving baek, in kind or in value, whatever had been given or done in compliance with the abandoned exchange"); Perillo, supra note 11, at 1222-25 ("restitution, when employed as a body of law to unwind contracts," performs "a contractual function," remedial rather than substantive, whose object is the restoration of the status quo ante and not the avoidance of unjust enrichment). 
the farmer chooses to reclaim his horse because it's too much trouble to sue for the value of the cow. By contrast, the rescission alternative becomes a valuable entitlement if it permits a party performing at a loss, on discovering a material breach by the other party, to forgo his damage claim (which would be negative) and sue in restitution for the value of his own interrupted performance, unlimited by the contract price. ${ }^{90}$ If such a remedy is allowed, the plaintiff's unfavorable bargain is nullified with retroactive effect. Restoration to the status quo ante, under such circumstances, gives the plaintiff more than his contractual entitlement. Rather, it augments the plaintiff's assets, precisely to the extent of the loss that performance of the contract would have entailed.

The propriety of such a remedy is notoriously controversial; ${ }^{91}$ but its correctness as a matter of contract law, for purposes of the present discussion, is essentially beside the point. Assume for the sake of argument that there exists a restoration interest-an entitlement to be restored to the status quo ante-that not only protects a plaintiff's property but occasionally allows him to escape the consequences of an unfavorable bargain. Why should we attempt to account for that restoration interest within the law of restitution? The orthodox proposition is that "restitution for breach of contract" serves to prevent the unjust enrichment of the defaulting party, but in reality it does nothing of the kind. ${ }^{92}$ By contrast, the arguinent for the existence of a "restoration interest" in contract law actually begins, quite correctly, by denying that restitution as a remedy for breach is prinarily concerned with the unjust enrichment of the defendant. ${ }^{93}$ Grant that prem-

90. See 1 PALMER, supra note $6, \S 4.4 \mathrm{n} .1$ (citing authorities for the availability of such relief).

91. See Kull, supra note 7, at 1470 . Resolution of the controversy requires a theory about why contract law allows a remedy of rescission in the first place. (The alternative would be a remedial regime limited to the various forms of contract enforcement.) Except where an avoidance remedy is expressly or impliedly adopted by the parties (in which case rescission becomes a form of enforcement), 1 have argued that rescission is justified by remedial efficiency: it serves as a less-bad alternative to enforcement in circumstances where enforcement, for one reason or another, would be unduly costly. Id. at 1502. It follows that rescission would not exist if the enforcement remedies were fully effective and costless, and that rescission should not be permitted (unless specified by the parties) where a contract is more easily enforced than unwound. See id. at 1499-1505. By contrast, if the plaintiff's right of rescission (with the concomitant ability to escape an occasional bad bargain) were justified by the need to protect plaintiffs (or punish defendants, or both) by a supercompensatory remedy for material breach, it might well be appropriate to allow rescission and recovery in quantum menuit at the plaintiff's election.

92. See, e.g., RESTATEMENT (SECOND) OF CONTRACTS $\S 344(c) \&$ cmt. a, § 373 \& cmt. a (1979) (identifying the "restitution interest" in contract remedies with the need to prevent the unjust enrichment of the party in breach). The orthodox account, according to which a party confronted with a material breach of contract may elect restitution as an alternative to damages in order to prevent the unjust enrichment of the defendant, is based on a faulty conjecture about the historical basis of the remedy in quasi-contract in this context, and on an illogical attempt to locate the source of the defendant's enrichment in contractual performance rather than in contract formation. See Kull, supra note 7, at $1485-90$.

93. See Corarn, supra note $89, \S 1107$, at 577 ; Perillo, supra note 11 , at 1213-15. 
ise, however, and there remains no particular reason (apart from the name) to regard restoration to the status quo ante as part of restitution at all.

Is there any reason why the body of law that describes liability for unjust enrichment need also concern itself with remedies that work by restoring something to someone, or by restoring someone to a previous condition? Restoration remedies have a characteristic association with rights of property. Beyond that, they serve the law of restitution as they serve contract and tort: as an occasionally superior remedial alternative to money compensation. It is time to admit the obvious. The connection between liability for unjust enrichment, on the one hand, and the restoration remedies, on the other, is that two unrelated concepts share a single name. Their cohabitation is awkward for everyone, because people keep assuming they must be related.

\section{III}

\section{RESTITUTION AS A REMEDY}

Because casebooks and treatises on the law of Remedies are at present the only sources from which an American lawyer is likely to obtain any coherent account of the law of restitution, ${ }^{94}$ it may seem churlish (as well as self-defeating) to complam that such works inevitably foster the impression that restitution is "a remedy" for wrongs defined by other theories of liability (thus putting restitution on a par with damages or injunctions), rather than an independent source of liability having characteristic remedies of its own. The distinction, moreover, is of no immediate practical significance. Where a defendant has committed a profitable wrong, the essential thing is to recognize that the law offers the plaintiff a choice of remedies, among them a monetary recovery measured either by harm to the plaintiff or benefit to the defendant. If the latter alternative is more advantageous, as in the case of a profitable trespass causing no injury to the plaintiff, ${ }^{95}$ there is a sense in which it does not matter whether we describe the result by saying that the law provides an alternative remedy in restitution for a tort liability, or that the basis of liability is the defendant's unjust enrichment at the expense of the plaintiff. The distinction is all the more abstract because both statements are perfectly accurate.

Nevertheless, our choice of analysis for this important subdivision of restitution makes a good deal of difference to the basic definition of the subject. If we say that restitution is sometimes a source of liability (as in cases of mistaken payments), sometimes a remedial alternative (as in cases where tortfeasors and infringers are held liable for profits rather than damages), then restitution is a doctrinal hybrid unlike anything else in our law. We could not say that contract, for instance, is sometimes an independent

94. Two notable examples are DoBBS, supra note 6, ch. 4, and LAYCock, supra note 47, ch. 6 .

95. See, e.g., Raven Red Ash Coal Co. v. Ball, 39 S.E.2d 231, 239 (Va. 1946) (allowing recovery in restitution for surcharge of an easement concededly causing no injury to servient tenement). 
source of liability and sometimes a remedy for tort. If we could say instead that every instance of restitution involves "recovery based on and measured by unjust enrichment,"96 the subject would not only be more easily described, but its status as an independent basis of liability (comparable to contract and tort) would be more readily apparent. If a unitary definition of restitution is preferable to a complex one, then-logic and accuracy permitting-we should avoid describing restitution as a remedial alternative for liabilities not founded on unjust enrichment.

Douglas Laycock builds his highly persuasive account of The Scope and Significance of Restitution upon an important and useful observation about overlapping theories of recovery. Although a recovery in restitution is theoretically available in the case of any profitable wrong, the accessibility of more familiar tort remedies will ordinarily mean that a defendant's liability in restitution has no more than academic interest. If a thief takes property worth $\$ 100$ and sells it for $\$ 100$, the victim might sue in quasicontract but is far more likely to sue in tort. The consequence, as Laycock points out, is that liability based on unjust enrichment is of practical interest only when it adds something to "the other sources of civil liability."97 This will be the case when unjust enrichment is the only basis of liability in conventional terms: for example, in cases of benefits conferred by mistake. It will also be the case whenever a plaintiff who could state a claim for damages in tort "prefers to measure recovery by defendant's gain, either because it exceeds plaintiff"s loss or because it is easier to measure."

Laycock takes this division in the cases as a point of departure from which to distinguish two forms of enrichment-based restitution, substantive and remedial: "restitution as the source of liability," as distinct from "restitution as the measure of recovery." He sees the distinction as not merely practical but analytical, arguing that in the second class of cases, restitution has only a remedial function. Thus "in ordinary torts and breaches of contract" plaintiff may elect between "his own damages" and "defendant's gain." Restitution in such cases is "remedial," not "substantive." The defendant's enrichment is therefore "simply an alternate measure of recovery for the underlying wrong," his liability being defined in terms of tort or contract or some other breach of duty. ${ }^{100}$

96. Laycock, supra note 10, at 1279 (noting that this definition of restitution is one of at least two ways that lawyers use the word).

97. Id. at 1284 .

98. Id.

99. Id. at 1286.

100. Id. Laycock adopts the same position in his casebook: "In cases like Olwell [the egg-washer case, discussed supra note 27], quasi-contract is simply a remedy for tort . . . Sometimes quasicontract is a source of liability as well as a remedy ..." LAYcocK, supra note 47 , at 466 (emphasis added).

To illustrate the purported distinction between substantive and remedial restitution, I have primarily quoted Douglas Laycock's statements because they are both representative and relatively familiar to 
The argument here, it bears repeating, is not about what judges do, merely about the most useful way to describe what they do. There are certain practical advantages to describing restitution as partly substantive and partly remedial. Such an account will focus attention on those situations in which a lawyer had better learn something about restitution. These advantages, however, come at the cost of making the law of restitution conceptually more complex. Thus for Laycock the law of restitution is ultimately tripartite:

Restitution should therefore be defined as that body of law in which (1) substantive liability is based on unjust enrichment, (2) the measure of recovery is based on defendant's gain instead of plaintiff's loss, or (3) the court restores to plaintiff, in kind, his lost property or its proceeds. ${ }^{101}$

The arguments for excluding the third element of this definition have already been canvassed at length. Should we not also view the first and the second elements as coextensive? We would thereby achieve a unitary definition of restitution: liability that is both "based on and measured by unjust enrichment." ${ }^{102}$ Is there any logical obstacle to this more attractive definition? Laycock argues as follows:

For substantive claims not dependent on the law of restitution-such as those based in ordinary torts and breaches of contract-plaintiff generally has an election. Plaintiff can always claim his own damages; alternatively, he can usually claim defendant's gain.

This election was traditionally thought to require plaintiff to sue for unjust enrichment rather than for tort or breach of contract, and thus to plead in quasi-contract or in equity. But this substantive dichotomy is misleading, because it is only the tort or breach of contract that makes the enrichment unjust. In these cases, restitution is remedial. Defendant's enrichment is now generally recognized as simply an alternative measure of recovery for the underlying wrong. ${ }^{103}$

American readers. I do not, however, mean to imply that Laycock's view is either unusual or idiosyncratic. Two eminent English authorities offer the same proposition in the following terms:

[T] ]he law of restitution is sharply divided as between restitution for wrongs and autonomous unjust enrichment .... Restitution for wrongs is a remedial inquiry about the availability of restitutionary (i.e. gain-based) damages for wrongs. This part of the law of restitution can equally be considered to be part of the law of wrongs and part of the law of remedies. However, autonomous unjust enrichment is a study of causes of action in unjust enrichment. The word 'autonomous' is put in to make clear that here the cause of action arises, not in the law of wrongs (torts, breaches of contract, breaches of equitable or statutory duty), but in the independent category of unjust enrichment.

Peter Birks \& Robert Chambers, The Restitution Research Resource vii (1994).

101. Laycock, supra note 10, at 1293.

102. Id. at I279.

103. Id. at 1286 (footnotes omitted, emphasis added). 
Peter Birks makes the same claim. "Where the victim of an acquisitive wrong seeks restitution in respect of the wrongdoer's gain"--so that "although he complains of unjust enrichment at his expense it is only by establishing the wrong that he can make out his case"- "his cause of action will be the wrong." 104

Such arguments propose one possible way of looking at the question, but they fall well short of a conclusive demonstration. The heart of the argument, the statement that "it is only the tort or breach of contract that makes the enrichment unjust," does not suffice to show that liability in such a case is founded on defendant's wrong as opposed to defendant's enrichment. This follows only if we assume the conclusion: that liability is in tort, for example, as opposed to unjust enrichment, whenever a tort action would lie. Take one of Laycock's examples, a case in which someone steals a hundred-dollar bill. The defendant's wrong simultaneously injures the plaintiff and enriches the defendant. The law imposes a liability of $\$ 100$, why? If both injuries and unjust enrichments are among the actuating circumstances of legal intervention, then (setting aside any presumptions) it is impossible to say whether the $\$ 100$ liability is based on the injury or the enrichment. The safe answer would be "both," though in such a case (as Laycock remarks) "it will rarely matter whether plaintiff recovers one hundred dollars in damages for the tort or one hundred dollars im restitution of the unjust enrichment." 105

In short, because the law of harms and the law of benefits afford overlapping grounds of liability in such a case (as both Laycock and Birks would presumably agree), the conclusion that the cause of action is based on the wrong and not the enrichment is a non sequitur. The defective syllogism, moreover, carries the misleading implication that restitution in this class of cases, where defendant's independently actionable wrongdoing is what "makes the enrichment unjust," is essentially different from restitution in cases where defendant's only wrong is the failure to account for a benefit received. In either case, however, there is a violation of a legal duty that makes the enrichment unjust, so the only real distinction is between an action and an omission. If a passive recipient is held liable in restitution, we inay properly infer that the law imposes an affirmative duty that the passive recipient has violated. This is the duty to restore or pay for a benefit that the recipient cannot conscientiously retain. ${ }^{106}$

104. BIRKs, supra note 13, at 41.

105. Laycock, supra note 10, at 1283.

106. As Ernest Weinrib has pointed out, the restitution defendant violates a duty to the plaintiff even though his receipt of the benefit was not the result of misconduct:

Unilateral transfers, such as mistaken payments, that are not the product of a donative intent are juridically ineffective, regardless of the absence of wrongdoing by the donee. Their restitution can therefore be demanded as a matter of corrective justice.

In such circumstances, the enrichment itself represents something that is rightfully the plaintiff's. Because its retention by the defendant is an infringement of the plaintiff's right, the defendant has a duty to restore it to the plaintiff. Liability is the juridical confirmation 
The question whether to separate the substantive and remedial aspects of restitution is purely one of classification. Its resolution will not change the outcomes of cases or even the rationale by which the outcomes are explained. And yet the analytical issue is an important one. As Laycock observes,

Defining fields and classifying remedies within them is an acadeinic enterprise, usually of little inoment to students. But here the dispute over definition is a dispute over how to implement a highly practical goal: how to state the law of restitution in simple and contemporary terms. ${ }^{107}$

Describing the law of restitution as substantive in some cases and remedial in others offers certain practical advantages, as both Laycock and Birks ably illustrate. Such a description is not logically compelled, however, and it obscures the underlying unity of restitution's reason and function across all of its factual settings. The simplest possible account of the law of restitution, consistent with the case law, will describe it as the branch of civil liability that is based on and measured by the unjust enrichment of the defendant at the expense of the plaintiff.

\section{IV}

\section{What Difference WILl it Make?}

The central problem of the law of restitution is to identify those instances of enrichment that the law regards as unjust; in other words, to distinguish benefits that have to be paid for from those that we can retain without payment. Understood in a broad sense, the problem of identifying unjust enrichment subsumes the other characteristic difficulties of the subject. These include the problem of measuring a restitutionary recovery (how much of this benefit, in the hands of this defendant, constitutes unjust enrichment?), as well as the defenses to restitution (are there additional circumstances, such as change of position or bona fide purchase, making it mappropriate to conclude that this defendant has been unjustly enriched?). Rationalizing restitution promises only marginal help with these issues; hard cases in restitution will still be hard cases. The primary purpose of explaining restitution exclusively in terms of enrichment is rather to build a more serviceable framework for analysis, one that will facilitate both agreement and argument over the proper workings of the unjust-enrichment principle.

Rationalizing restitution will also make some difference in the cases, if only because "restitution without enrichment" will be recognized, without qualification, as a contradiction in terms. Clearer doctrine does not neces-

\footnotetext{
that, by holding on to the factual gain, the defendant breaches a duty that is correlative to the plaintiff's right.

Ernest J. Weinrib, The Idea of Private Law 141 (1995) (footuote omitted).

107. LAYCOCK, supra note 47 , at 654 .
} 
sarily mean different results. Where a loose conception of restitution has served as a conveniently vague explanation of results that might better be explained in contract or tort-as is true of most instances of "restitution" as a contract reniedy - the practical difference may be merely that the sanie outcomes are given a more candid explanation. By contrast, where liability in restitution is essentially freestanding - so that a plaintiff must logically recover in enrichment-based restitution or not at all-an insistence on defendant's unjust enrichment as part of the plaintiff's prinia facie case may require that some cases be decided differently. The principal source of such cases is probably the general area of benefits conferred by mistake.

Even where the consequence of rationalizing restitution is merely a different explanation of the same result, such a development is desirable if it leaves us with a clearer idea both of restitution and of some neighboring doctrine. For example, if we can agree that the owner of the bathhouse im Vickery $v$. Ritchie has not been enriched by its construction beyond the greater of any increase in the assessed value of his property and the price he expressed a willingness to pay-as I have argned above, and as John Dawson appears to have assumed in his discussion of the case ${ }^{108}$ - then our first conclusion is that whether or not the builder is entitled to recover anything, he has no claim in restitution. ${ }^{109}$ If the builder recovers anyway, it is on some other basis of liability that must now be made explicit: something in the circumstances of the transaction making it appropriate to shift from the builder to the owner the loss resulting from a contractual casualty (im this case, a value-reducing transfer induced by the fraud of a third party). If the rationale for loss-shifting is made explicit, the result may be the same, but contract doctrine will to that extent be clarified. On the other hand, if a persuasive rationale for loss-shifting is not available, Vickery $v$. Ritchie will have to be decided differently.

In the same way, where the value of contractual performance is destroyed by supervening circumstances-as when specially built machmery becomes undeliverable with the outbreak of war, or when a building under repair is consumed by fire ${ }^{110}$ _rationalized restitution doctrine will no longer allow recovery in restitution for what are manifestly nonexistent benefits. In such cases, the parties' sunk costs of partial performance represent casualty losses. Where the risks of such losses are not assigned by the parties' agreement, it niay be desirable to develop rules by which the losses themselves, if realized, can be shifted or split ex post. The suggestion,

108. See supra text accompanying notes 57-65; Dawson, supra note 9, at 594-96 (arguing that the owner should pay the cost of services rendered at his request, despite the fact that such cost exceeded the benefit received).

109. The owner in Vickery had already paid the price shown in his copy of the contract, an amount that was greater than the increase in assessed value attributable to the improvement. See Vickery v. Ritchie, 88 N.E. 835, 835 (Mass. 1909). The whole of the builder's claim was therefore for compensation in excess of the owner's measurable cnrichment.

110. See supra text accompanying note 55 . 
however, that restitution authorizes a judicial apportionment of unassigned losses from frustrated contracts obscures both the nature of restitution and the reality of what judges in such cases are actually doing.

\section{A. Defining the Prima Facie Case}

Where a plaintiff asserts a claim for a benefit conferred by mistakemost typically, a mistaken payment of money-the recipient will be liable on a theory of restitution or not at all. It is here (as opposed to the contract cases) that rationalizing restitution is more likely to change outcomes. The question is whether the plaintiff may state a prima facie case in restitution merely by alleging that he has conferred a benefit by mistake on the defendant, or whether the plaintiff must further allege that, as a result of his mistake, the defendant has been unjustly enriched. Possible defenses to restitution-bona fide purchase, "discharge for value," tion-will eliminate the significance of the distinction in many cases but not all.

To see the consequences of this distinction in practice, consider a classic commercial law scenario in which a bank mistakenly pays a check over a customer's stop order. The bank's attempt to recover the money raises directly the question of the prima facie case in restitution, because the payment in question may in fact have been due to the recipient. Thus, while the bank has unquestionably made a mistaken payment, the recipient may or may not be unjustly enriched if it retains the money.

Imagine a simple case in which a check is written by a buyer to a seller im payment for goods. After sending the check, buyer discovers what he considers (rightly or wrongly) to be a defect in the goods, giving him, as he interprets the applicable warranties (again rightly or wrongly), grounds for revocation of acceptance. Buyer stops payment; the bank mislays the stop order and pays the check. The bank is liable to its customer, the buyer, and the bank would like to sue soineone in restitution to recover the mistaken payment. But the imcidence of enrichment in such a case necessarily depends on the rights of the parties to the underlying sales contract. If the buyer was right about the defect and the warranty, seller's retention of the mistaken payment would constitute unjust enrichment. If the buyer was entitled to rescind as to part of the goods only, seller would be unjustly enriched pro tanto. Suppose, however, that the buyer was wrong about the warranties, or that (although the buyer was right about the warranties) the check had come into the hands of a holder in due course. Now the bank's

111. "Discharge for value" is the term devised by the Restatement of Restitution to deseribe the situation in which a defendant claims status as a bona fide purchascr on the strength of the release or discharge of a previously existing claim: the "discharge" constitutes the "value" that must be given to entitle the defendant to protection. See Restatement of Restrutuon $\S 14$, cmt. a \& reporters' notes (1936). Standing alone, the expression "discharge for value" is decidedly obscure. Its meaning must be deduced from the proximity of $\S 13$ ("Bona Fide Purchaser") and the notes accompanying both scctions. 
mistaken payment has discharged an unavoidable obligation of the buyer, and it is the buyer, not the seller, who will be unjustly enriched if the bank is unable to recover its outlay.

In this country the problem is governed by statute, and the statutory solution fully respects an enrichment-based theory of restitution. The fact that the bank made a mistake in paymg the check is not grounds, in and of itself, to recover the payment: the Uniform Commercial Code denies a direct recovery by the bank against a payee who took the check in good faith and for value, ${ }^{112}$ a condition satisfied by any creditor not engaged in fraud. In other words, the U.C.C. applies the rule of Price $v$. Neal to the case of a check paid over a stop order. ${ }^{13}$ The bank may, in fact, recover some or all of its mistaken payment, but not necessarily from the payee of the check, and only to the extent that the bank can demonstrate the unjust enrichment of some party on the facts of the transaction as a whole. The Code solution, in effect, is to subrogate the bank to whatever valid claims its mistaken payment may happen to have discharged. Depending on the circumstances, these will include claims against the drawer/buyer (asserted by the seller under the sales contract or by a holder in due course of the check), as well as claims against the payee/seller (asserted by the buyer under the seller's warranties). ${ }^{114}$

Note that the burden is on the bank to establish the unjust enrichment of the party from whom the bank seeks to recover. In our simple example, the bank must prove either that the buyer had a defense to payment under the sales contract (thereby establishing the unjust enrichment of the seller), or that the mistaken payment, or some part of it, was in fact due either to the seller or to a holder in due course of the check (thereby establishing the unjust enrichment of the buyer).

In England, where the question has not been resolved by statute, the check paid over a stop order still presents a problem in common-law restitution. The leading English decision, Barclays Bank Ltd. v. W.J. Simms Son $\&$ Cooke (Southern) Ltd., ${ }^{115}$ stands in sharp contrast to the U.C.C. rule, and we shall conclude that it was wrongly decided. The fact that English law adopts a different rule may be, in itself, of academic interest only. The case is worth our attention, however, because it illustrates so clearly both the essential choice to be made in defining the prima facie case in restitution and the practical consequences that can flow from the definition. Simms

112. See U.C.C. $\$ 3-418(1990)$. The check is issued "for value" if it is given "as payment of ... an antecedent claim against any person, whether or not the claim is due." Id. § 3-303(a)(3) (1990).

113. See id. $\S 3-418 \mathrm{cmt}$. 1 (stating that the section is consistent with "the rule of Price v. Neal"). The rule denies restitution to a bank that pays a forged or overdrawn check to a person who took the instrument in good faith and for value. Price v. Neal, 3 Burr. 1355, 1357, 97 Eng. Rep. 871,872 (K.B. 1762).

114. See U.C.C. $\$ 4-407$ (1990) (payor bank's right of subrogation "to prevent unjust enrichment").

115. [1980] 1 Q.B. 677 (1979). 
defines the prima facie case for recovery of mistaken payments in a manner that omits any requirement of the defendant's enrichment. The result is all the more noteworthy because it is presented in a very careful opinion by Justice Robert Goff (now Lord Goff), co-author of the authoritative English treatise on restitution. ${ }^{116}$

In Simms, a customer of the bank sent a check to the defendant, a firm of builders, as a progress payment on a building under construction. Payment was pursuant to the customary certificate by the owner's architects. The next day the building firm went into receivership. The contract provided that in the event of the builder's receivership, the owner might withhold "any further payment" pending an accounting and set-off of any losses to the owner in consequence thereof. The owner instructed the bank to stop payment on the check it had previously sent to the builder. On the same day, or early the next, the check was presented for payment by the builder's receiver, who had no knowledge of the stop order. The bank paid the check by mistake, then sued the receiver to recover the amount of the payment. ${ }^{117}$ The court held that the money was recoverable by the bank, leaving the builder (and its receiver) to pursue their remedies against the owner in a separate action. ${ }^{118}$ Concluding a painstaking review of the English authorities, Justice Goff found the basis of the bank's recovery in the rule that "[i]f a person pays money to another under a mistake of fact which causes him to make the payment, he is prima facie entitled to recover it as money paid under a mistake of fact." 119 This manner of stating the rule is useful for purposes of comparison, because it describes a prima facie case in restitution froin which the unjust enrichment of the defendant is notably absent. Applied to the payment of a check over a stop order, it authorizes a bank to recover in restitution from every payee, regardless of whether the defendant, on the facts of the underlying transaction, is unjustly enriched by retention of the payment. ${ }^{120}$

116. See generally GoFF \& JoNEs, supra note 17.

117. [1980] I Q.B. at 682-85.

118. Id. at 703 .

119. Id. at 695. The principal and praiseworthy objective of Justice Goff's opinion in Sinints was to repudiate an awkward line of English authorities artificially limiting the availability of restitution for the recovery of mistaken payments. The suggestion of some older cases was that a causal connection between the mistake and the payment was not enough; rather, the mistake in question had to be either a mistake as to the payor's liability to the payee, or in some other way a mistake "as between" payor and payee. See id. at 690-95. As stated in one leading case, "[i]n order to entitle a person to recover back money paid under a mistake of fact, the mistake must be as to a fact which, if true, would make the person paying liable to pay the money." Aiken v. Short, 1 H. \& N. 210, 215, 156 Eng. Rep. 1180, 1182 (Exch. 1856). Such a limitation has no foundation in history, principle, or policy, and it plainly cannot coexist with the idea that restitution is founded on unjust enrichment. Despite an early attempt by Woodward to engraft it onto the American law of restitution, it has had little infiuence on judges in this country. See Frederic Campbell Woodward, The Law of Quasi Contracts $\S 18$ (1913); cf. 3 PALMER, supra note 6, § 14.2.

120. The court acknowledged the possibility of affirmative defenses in the form of bona fide purchase and change of position, but held that neither was available to the builder on the facts of the 
The quarrel is not merely with an abstract statement of the legal rule. On the facts of the case, it appears entirely possible that Simms imposed liability in restitution on a defendant who was not unjustly enriched by the plaintiff's mistake. Because the check represented a progress payment based on an architect's certificate, it is reasonable to assume that the amount of the check had been earned and was owed to the payee under the building contract. Assuming that the owner's attempt to stop payment was contractually justified, $m$ that the owner had a right to suspend payments pending an accounting and set-off of costs incurred by reason of the builder's receivership, the owner's liability to pay the builder was not otherwise discharged (except to the extent that such costs might in fact be incurred). Under these circumstances, it is most unlikely that the builder would be unjustly enriched-by comparison with its contractual entitlement-if the owner made one more scheduled payment before asserting its rights of set-off. So far as enrichment is concerned, the analysis is the same whether the extra payment is the result of the bank's negligence or of the owner's own inadvertence in making a payment it might justifiably have deferred.

We might describe the situation by saying that the builder had an apparently valid claim against the owner which a provision of their contract rendered temporarily unenforceable. So regarded, the situation in Simms resembles the archetype of the mistaken payment that (according to Lord Mansfield) is not recoverable in restitution: the mistaken payment to a creditor of a valid debt barred by the statute of limitations. ${ }^{121}$ Lord Mansfield's insistence that circumstances had a bearing on the equities of the case, permitting a distinction between payments that might or might not be "conscientiously" retamed by a defendant, is simply obliterated by Justice Goff's statement of the prima facie case for recovery of mistaken payments. Indeed, the test as stated in Simms would allow restitution to the bank even if the drawer asserted no legal or contractual basis for its attempt

case. There was, in fact, no suggestion that the builder (or its receiver) had changed position on receipt of the money; the mistaken payment could therefore be reversed without creating additional hardship. Simms, [1980] 1 Q.B. at 703. The defense of bona fide purchase, by contrast, is one that would have been available under American law. See supra text accompanying notes 112-113. It was dismissed in Simms with the hypertechnical and, from an American standpoint, singularly unpersuasive observation that "since the drawer had in fact countermanded payment, the bank was acting without mandate and so the payment was not effective to discharge the drawer's obligation on the cheque; from this it follows tbat the payee gave no consideration for the payment, and the claim cannot be defeated on that ground." [1980] 1 Q.B. at 703.

121. In his best-known description of the action in restitution, Lord Mansfield emphasizes that it does not lie for money paid by the plaintiff, which is claimed of him as payable in point of honor and honesty, although it could not have been recovered from him by any course of law; as in payment of a debt barred by the Statute of Limitations, or contracted during his infancy, or to the extent of principal and legal interest upon an usurious contract, or, for money fairly lost at play: because in all these cases, the defendant may retain it with a safe conscience, though by positive law he was barred from recovering.

Moses v. Macferlan, 2 Burr. 1005, 1012, 97 Eng. Rep. 676, 680-81 (K.B. 1760). 
to stop payment of its check: for instance, if the drawer's reason for countermanding payment was merely that it had changed its mind and wanted to conserve cash by delaying payments to its creditors.

The prima facie case stated in Simms gives a claim in restitution where Lord Mansfield would have denied it, because it omits entirely the traditional equitable element of the restitution claim. Simms thus brings us back to the starting point, requiring us to determine whether restitution is really about unjust enrichment or inerely about reversing questionable transfers. Many cases in restitution can be decided without knowing the answer to that question, but others (like Simms) will turn on the distinction.

\section{B. Reexamining the Affirmative Defenses}

In other factual settings, the debate about the significance of unjust enrichment to a recovery in restitution takes the form of an argument about affirmative defenses. Taken at face value, the affirmative defenses to restitution invite an inquiry into the balance of equities between the parties. The defendant concedes that he received a benefit of a kind for which the plaintiff might ordinarily recover in restitution; he pleads, nevertheless, that circumstances make it inequitable to hold him liable. The equitable foundation of the defenses was formerly explicit. When Lord Mansfield could summarize liability in restitution by saying "that the defendant, upon the circumstances of the case, is obliged by the ties of natural justice and equity to refund the money," 122 his definition of the affirmative defense was merely the converse of the prima facie case: "every thing which shews that the plaintiff, ex aequo \& bono, is not entitled to the whole of his demand, or to any part of it."123 Because such broad equitable directives offer little help in deciding cases, the law of restitution has seen a conscious effort to replace the soft-edged standard of ex aequo et bono with simple and predictable rules for recurring commercial situations. The defense of bona fide purchase, in particular, has become a schematic and mechanized version of a defense that was originally conceived in purely equitable terms.

The simplest of the affirmative defenses, the estoppel-based notion of "change of position," remains uncontroversial and relatively easy to apply. The recipient of a mistaken payment who (unwittingly) has irretrievably spent the money will suffer hardship if asked to return it; to this extent, the defendant's equity counterbalances the plaintiff's, with the result that restitution will be denied. ${ }^{124}$ The second principal defense to restitution, bona fide purchase, is harder to deal with. Ideas of good faith purchase tend to

122. Moses, 2 Burr. at 1012, 97 Eng. Rep. at 681.

123. Id. at 1010, 97 Eng. Rep. at 679. Or as Lord Mansfield put it on another occasion: "[T]he defence [to restitution] is any equity that will rebut the action." Sadler v. Evans, 4 Burr. 1984, 1986, 98 Eng. Rep. 34, 35 (K.B. 1766).

124. See, e.g., Mutual Life Ins. Co. v. Metzger, 172 A. 610, 612 (Md. 1934) (overpayment of life insurance proceeds not recoverable in restitution to the extent the money has been spent, in good faith, on additional funeral expenses). 
be invoked in circumstances in which the weighing of equities between the parties may seem both difficult and beside the point. It was in this spirit that the Restatement of Restitution decided to treat bona fide purchase as if it had nothing to do with competing equities, making it imstead merely a rule of thumb to facilitate the resolution of certain recurrent disputes. ${ }^{125}$ There are, of course, legal settimgs in which it is more important to have a clear rule than an equitable rule, and some familiar problems in restitution are doubtless among them. It is uncomfortable, nevertheless, to have to justify a legal rule by saying that we are not concerned with a just result, especially (as in the case of any claim in restitution) where the underlying premise of liability is equitable in nature. If a defense is then mechanically applied to decide a case of a kind that does not necessitate a mechanical rule, the theory of the affirmative defense has been allowed to stultify the theory of the action. Rationalizing restitution invites a reexamination of any outcome in which defendants who appear to be unjustly enriched are allowed an affirmative defense, or in which defendants who do not appear to be unjustly enriched are denied one.

The doininant modern insight about bona fide purchase is that it serves a valuable commercial function by safeguarding the finality of transactions.

125. Thus Warren Seavey described for the Restatement of Restitution a doctrine of bona fide purchase that was explicitly divorced from any equitable foundation, claiming that

as a new matter and from the standpoint of justice the result reached in any particular case might equally well be opposite to the result now reached under the rules. In other words, the rules as to bona fide purchase are not, as are the rules normally applicable to questions involving restitution, based upon the balance of justice between the parties, but merely upon technicalities.

Restatement of Restitution $§ \S 13,14$ reporters' notes (1936). Seavey protested too much; the audacious claim that the doctrine of bona fide purchase had nothing to do with "the balance of justice between the parties" must have caused Lord Mansfield to turn in his grave. The famous case of Price $v$. $\mathrm{Neal}$ was the quintessential commercial dispute, involving the rigbts in restitution of a drawee who has paid or accepted a negotiable instrument by mistake, against a holder who purchased the instrument for value and without notice of irregularity. Even here, however, Lord Mansfield took paius to explain his decision in explicitly equitable terms:

It is an action upon the case, for money had and received to the plaintiff's use. In which action, the plaintiff can not recover the money, unless it be against conscience in the defendant, to retain it: and great liberality is always allowed, in this sort of action.

But it can never be thought unconscientious in the defendant, to retain this money, when he has once received it upon a bill of exchange indorsed to him for a fair and valuable consideration, which he had bona fide paid, without the least privity or suspicion of any forgery.

Price v. Neal, 3 Burr. 1354, 1357, 97 Eng. Rep. 871, 872 (K.B. 1762). For a century and a half thereafter, the standard textbook explanation of bona fide purchase was that because such a purchaser had an "equal equity" to that of the plaintiff, it was not "unconscientious" of him to retain the asset in dispute. See, e.g., F.W. MAITLAND, EQUTTY 119 (1909) (purehaser in good faith "has done no wrong, he has acted honestly and with diligence. Equity cannot touch him, because, to use the old phrase, his conscience is unaffected by the trust."); 2 JoHn NORTON POMEROY, A Treatise ON Equity JuRISPRUDENCE $\$ 738$ (1882); 1 JoSEPH STORY, COMMENTARIES ON EQUITY JuRISPRUdENCE $\$ \S 57,139$, 165, 381, 435 (1835); J.B. Ames, Purchase for Value Without Notice, 1 HaRv. L. Rev. 1, 3 (1887) ("[C]ourt of equity will compel the surrender of an advantage by a defendant whenever, but only whenever, upon grounds of obvious justice, it is unconscientious for him to retain it at another's expense."). 
The good faith purchaser is said to be protected, "not because of his praiseworthy character"- the iinplication being, not because of the equities of his position-but rather "to the end that commercial transactions may be engaged in without elaborate investigation of property rights." 126 Finality is an undeniably significant objective in the regulation of ordinary commercial transactions, but it is conceptually awkward as a limit to claims in restitution because the two ideas are fundamentally at odds.

The goal of finality emphasizes the undesirable effects that will flow from the mere possibility of reopening a conipleted transaction. Restitution starts from a contrary perception: that in certain circuinstances out of the ordinary, the avoidance of unjust enrichment justifies not only the cost of judicial imtervention to reopen a transaction that would otherwise be over and done with, but also the cost of the additional uncertainty inevitably resulting from the mere possibility of such intervention. As a rationale for defenses to restitution, therefore, finality proves too much, because the goal of finality would best be served by a rule of no restitution at all. ${ }^{127}$ Defenses to restitution are conceptually coherent, by contrast, where the requirements of an affirmative defense, if made out by the defendant, tend logically to refute the claim that he has been unjustly enriched.

One imtriguing line of cases presenting these issues involves restitution for payments between successive fraud victims. In the usual setting, a swindler has borrowed money on fraudulent security such as a lien on stolen goods, or a mortgage of real estate owned by someone else. Finding a second lender willing to make a larger loan on the same security, the swindler directs the second victim to pay the first victim to release the prior "lien." The second victim eventually learns what has happened and sues the first victim in restitution.

A narrow emphasis on the techmicalities of bona fide purchase has led to conflicting decisions in cases that appear indistinguishable in terms of unjust enrichment. Thus in Gaffner v. American Finance Co. ${ }^{128}$ a swindler obtained money from the defendant in exchange for a promissory note secured by a lien on a stolen car. The plaintiff, a would-be purchaser of the car, paid the defendant to discharge the supposed lien. Restitution of this payment was denied, although the only value given by the defendant was the surrender of his claim against the swindler in personam. ${ }^{129}$ By contrast,

126. Grant Gilmore, The Commercial Doctrine of Good Faith Purchase, 63 YALE L.J. 1057, 1057 (1954).

127. For example, a hypothetical rule that denied any action in restitution to recover mistaken payments would plainly promote the objective of finality. Morcover, it would create incentives to greater precautions by persons making payments that might (for all we know) yield incrcased efficiency in commercial transactions generally. The fact that our law allows restitution in this situation reveals the presence of a competing objective, namely the desire to avoid unjust enrichment.

128. 206 P. 916,917 (Wash. 1922).

129. Id. at 918. Additional decisions denying restitution where plaintiff discharges defendant's licn on a stolen car include Hilliard v. Bank of America Nat'l Trust \& Sav. Ass'n, 228 P.2d 327, 331 (Cal. Ct. App. 1951); Associates Discount Corp. v. Clements, 321 P.2d 673, 679 (Okla. 1958); Krebs v. 
the swindler in National Shawmut Bank v. Fidelity Mutual Life Insurance Co. ${ }^{130}$ obtained loans on someone else's life insurance policies by forging the signature of the policyholder on the loan documents. He later refinanced the policy loans with a bank loan on more favorable terms, forging the policyholder's name again and pledging the policies as security. Proceeds of the bank loan were used to repay the policy loans. In a suit by the bank against one of the insurance companies, the court granted restitution. ${ }^{131}$ The defendant gave no "value" because it merely surrendered a claim (a forged promissory note secured by a forged pledge) that never really existed. ${ }^{132}$

Torturing the notion of bona fide purchase in these cases is only a way to avoid the real issue in restitution. Was the defendant unjustly enriched by receipt of the plaintiff's payment? The usual question is unusually difficult in this setting, because the answer depends so obviously on where we decide to fix the baseline by which to measure the defendant's enrichment. Conflicting opinions in which judges emphasize either that plaintiff's payment merely left the defendant back where he started (hence no enrichment), or else that by the time defendant received plaintiff's payment he had already lost his money to the swindler (hence enrichment), only drive home the poimt that it all depends on how you look at it.

In such a case there may be no alternative to addressing the question Lord Mansfield's way, by an inquiry into the balance of justice between the parties. One approach that might be helpful is to inquire whether the plaintiff and the defendant were similarly situated with respect to the third party whose actions gave rise to the loss that one of them inust now suffer. ${ }^{133}$ In

World Fin. Co., 14 D.L.R.2d 405, 407-08 (B.C. App. 1958). Compare the decisions denying restitution between victims deceived by successive forged mortgages: Russell v. Richard \& Thalheimer, 60 So. 411, 414-15 (Ala. Ct. App. 1912), cert. denied, 61 So. 819 (1913); Cal. Pac. Title \& Trust Co. v. Bank of America Nat'l Trust \& Sav. Ass'n, 55 P.2d 533, 537 (Cal. Ct. App. 1936); Walker v. Conant, 37 N.W. 292, 295 (Mich. 1888).

130. 61 N.E.2d 18, 19-20 (Mass. 1945).

131. Id. at 23 .

132. This is the principal explanation offered in National Shawmut. See id. at 21; cf. Restatement OF RESTITUTION $\S 14$ illus. 6-7, reporters' notes (1936) (advancing technical grounds for the availability of a defense in the National Shawmut situation). Additional cases allowing restitution between successive lenders on fraudulent security (typically, forged mortgages of real estate) include Strauss v. Hensey, 9 App. D.C. \$41, 547-48 (1896); St. Paul Fed. Sav. \& Loan Ass'n v. Avant, 481 N.E.2d 1050, 1057 (Ill. App. Ct. 1985); Grand Lodge, A.O.U.W. v. Towne, 161 N.W. 403, 407 (Minn. 1917).

133. Comparing the situations of plaintiff and defendant vis-à-vis a third party is the usual way to resolve some standard problems in restitution, in particular the recurring fight between the restitution plaintiff (claiming to be a fraud victim) and the general creditors of an insolvent debtor. Where the restitution claim is allowed, the justification for allowing a priority over the creditors is that the bankrupt estate would otherwise be increased (thereby enriching the creditors) by a transaction that was involuntary on the part of the plaintiff, in that the creditors accepted the risk of the debtor's solvency and the fraud victim did not. By contrast, where the claimant's relation to the debtor cannot be satisfactorily distinguished from that of other creditors, restitution is properly denied. See, e.g., In re North Am. Coin \& Currency, Ltd., 767 F.2d 1573, 1577-78 (9th Cir. 1985) (where plaintiffs constituted "only one of several comparable groups of creditors," distinguishable primarily by the timing and sequence of their 
typical cases of restitution between successive fraud victims, the fact that plaintiff and defendant are identically situated-in that their dealings with the swindler are likely to be indistinguishable-makes it difficult to conclude that one has been enriched at the expense of the other. ${ }^{134}$ They appear rather to have been unwitting participants in a game of musical chairs: the incidence of the loss is determined almost by chance, and it seems artificial to describe anyone but the swindler as having been "enriched" in the process.

Conversely, some restitution defendants who currently enjoy technical status as bona fide purchasers would be more likely to face liability if a rationalized doctrine focused closer attention on the underlying question of enrichment. A significant set of such cases involves mistaken payments that are credited by their recipients toward the discharge or satisfaction of preexisting obligations owed to the recipients by third parties. The most characteristic example is a payment mistakenly directed to somebody else's overdrawn bank account.

Standard doctrine, strongly influenced by the Restatement of Restitution, treats the bank in this situation as a kind of bona fide purchaser under the rubric of "discharge for value." ${ }^{135}$ Recognizing a defense to restitution in such circumstances has potentially dramatic consequences. The mistaken payment, in today's banking system, nay well be a inisdirected wire transfer for a very large sum. The reason that the receiving bank did

otherwise equivalent transactions with the debtor, no equitable principle entitled them to priority over creditors similarly situated), cert. denied, 478 U.S. 1083 (1986).

134. Compare the old case in which one Bean, a ne'er-do-well Yankee inventor, was indebted to an engineering firm for work done on a model of his latest invention. See Concord Coal Co. v. Ferrin, 51 A. 283, 283 (N.H. 1901). When pressed for payment, Bean advised his creditors that local coal merchants were backing his project, and that they would supply a ton of coal in part payment of his debt. The engineers agreed to accept coal on that basis. Bean thereupon advised the coal merchants that the engineers wanted a ton of coal, saying nothing about any arrangement for payment. Between Bean and the coal merchants there was, of course, no business relationship whatever. The coal was delivered and used. When the engineers refuscd to pay, the coal merchants sued in restitution for the value of the coal. Restitution was denied, the court finding "no equitable rcason why the plaintiffs rather than the defendants should be released from the consequences of their trust in Bean." Id. at 285.

135. See supra note 111. Representative cases in which "discharge for value" is successfully interposed as a defense to restitution include Bowling Green, lnc. v. State St. Bank \& Trust Co., 425 F.2d 81, 85-87 (1st Cir. 1970) (where buyer sought to recover check negotiated to fraudulent seller on the eve of the seller's bankruptcy filing, and the amount of the check had been applied by seller's bank on the day of the filing (i) to cover an overdraft in seller's current account and (ii) to reduce the outstanding balance in seller's loan account, bank as holder in due eourse had superior elaim to the instrument); Weiner v. Roof, 122 P.2d 896, 897-99 (Cal. 1942) (where plaintiff sought to recover funds paid to bank for the account of a third party on the grounds that payment was fraudulently induced, and bank had applied the payment to reduce the balance of the third party's outstanding loan, bank had a superior claim to the funds); Banque Worms v. BankAmerica Int'l, 570 N.E.2d 189, 191 (N.Y. 1991) (where misdirected wire transfer resulted in funds being applied to reduee the payee's loan obligation to the receiving bank, receiving bank had a superior claim to that of payor bank); cf. Bank of America Nat'l Trust \& Sav. Ass'n v. Sanati, 14 Cal. Rptr. 2d 615, 621 (1992) (where creditor received mistakcn payment on account of an inchoate obligation of debtor, not yet redueed to judgment, defense of "discharge for value" could not be interposed, and recipient was liable to payor in restitution). 
not return the money on request-the reason there is litigation at all-is almost certainly that the person whose obligation was reduced by the mistaken payment was insolvent when the payment was made or became insolvent shortly thereafter. The availability of the affirmative defense can accordingly determine the incidence of a significant loss. It is noteworthy, therefore, that by the standards of rationalized restitution-in which the justification for any affirmative defense must be its tendency to show the absence of unjust enrichment- the rationale of discharge for value is precarious at best.

A recent New York case involving a mistaken wire transfer gives us the modern setting of the problem. The New York decisions left uncertain until recently whether New York recognized discharge for value as an affirmative defense to restitution for mistaken payments. One view of the case law, urged by restitution plaintiffs in these situations, was that New York recognized an affirmative defense only when the defendant could prove a detrimental change of position as a result of receiving the mistaken payment. ${ }^{136}$ In Banque Worms v. BankAmerica International, ${ }^{137}$ the New York Court of Appeals, responding to a certified question from the United States Court of Appeals for the Second Circuit, ${ }^{138}$ adopted the more liberal version of the defense, holding that discharge for value was a valid defense to restitution for mistaken payments.

In fact, the circumstances of Banque Worms illustrate the difficulty of stating a satisfactory rationale for discharge for value, whether in commercial or equitable terms. Pursuant to instructions from Spedley Securities, an Australian corporation, but disregarding a stop-payment order that countermanded the original instructions, Security Pacific International Bank sent nearly $\$ 2$ million by wire transfer to Banque Worms. The money was due and payable from Spedley to Banque Worms. (Indeed, Banque Worms's demand for payment was the occasion of the original transfer instructions, before Spedley changed its mind and directed that the money be sent instead to another of its creditors.) Banque Worms thus received the funds with no indication of any mistake and applied them in satisfaction of a valid obligation. Banque Worms was promptly requested to return the money; Banque Worms proinptly refused. Security Pacific then attempted to obtain the funds from Spedley, but by this time-only a few days, apparently, after the mistaken transfer-Spedley had entered involuntary liquidation. ${ }^{139}$

136. "To assert a valid defense to [plaintiff's] mistaken payment/money had and received cause of action, [defendant] must demonstrate detrimental reliance on the subject payment." Manufacturers Hanover Trust Co. v. Chemical Bank, 559 N.Y.S.2d 704, 710 (App. Div. 1990), leave to appeal denied, 568 N.Y.S.2d 15 (1991).

137. 570 N.E.2d at 198.

138. See Banque Worms v. BankAmerica lnt'l, 928 F.2d 538 (2d Cir. 1991), aff'g 726 F. Supp. 940 (S.D.N.Y. 1989).

139. Id. at $539-40$. 
When the positions of the parties involved in the wire-transfer chain had sorted themselves out, Security Pacific was asserting a claim in restitution against Banque Worms to recover the funds as money paid by mistake. Banque Worms's affirmative defense was that its discharge of Spedley's debt made it, in effect, a bona fide purchaser. ${ }^{140}$ (Having done nothing other than receive the money and post the credit, Banque Worms could not assert that it had suffered any change of position.) The Court of Appeals held that New York law barred the restitution claim in these circumstances. It thus approved the rule of discharge for value, based on the authority of the Restatement and on "the policy goal of finality in business transactions."141

Yet if the function of the affirmative defense $\mathrm{m}$ this circumstance were merely to safeguard ordinary commercial reliance-like the rules protecting the bona fide purchaser of goods, or the holder in due course of a negotiable instrument- the practical objective would be fully secured by the defense of change of position. Suppose, for example, that Banque Worms had made a secured loan to Spedley; and that the bank, on receiving the supposed payment, had released its security before it received notice that the wire transfer was unauthorized. Facts such as these would give the bank a defense to restitution under any version of the affirmative defenses, including the stricter New York rule rejected in Banque Worms. Discharge for value is questionable precisely because it protects the recipient bank where there has been no change of position. The result may be, as it was in this mstance, a staggering windfall to the recipient. Banque Worms avoided a loss of up to $\$ 2$ million on its loan to Spedley, because Security Pacific transferred $\$ 2$ million without authority to do so.

The Court of Appeals referred to finality of payments as the principal commercial objective underlying the rule of discharge for value, but a finality rationale will not explain the scope of the affirmative defense as it actually exists. Considerations of finality and commercial convenience would tend to support a much broader defense: a rule, for example, denying restitution of any mistaken payment that was received in good faith and without notice of the inistake. By contrast, the real reach of the defense in practice is sharply linnited by the requirement that the recipient give something up on receipt of the inistaken payment. If the same inisdirected wire transfer is posted to a bank account with a positive as opposed to a negative balanceto an ordinary checking account, say, instead of to a loan account-there is (barring some justifiable change of position) no defense to restitution on the part of the recipient. The overwhelming majority of mistaken payments, whether accomplished by paper or electronic means, are for this reason subject to restitution. The reason for the "value" component of bona fide purchase doctrine has always been that the defense rests on an equitable as

140. Id. at 540 .

141. Banque Worms, 570 N.E.2d at 196. 
well as a commercial justification. The bank that has applied a mistaken payment in satisfaction of a third party's preexisting obligation points to its release of the debt as offsetting value: the bank denies, in other words; that it has been enriched by the transaction when viewed as a whole. The force of this contention-as in the case of restitution between successive fraud victims - depends on what we identify as the baseline for measuring enrichment and on the balance of justice between the parties.

How the balance comes out must depend, first of all, on the consequences of allowing or denying restitution in the circumstances of a given case. Imagime the same mistaken wire transfer, discharging the same obligation, the only difference being that Spedley is still solvent and creditworthy. In such a case the result of giving Banque Worms a defense to restitution (discharge for value) is merely that Security Pacific is put to the trouble of obtaining repayinent from Spedley. ${ }^{142}$ This is not an unreasonable consequence of Security Pacific's inistake. In this hypothetical situation, moreover, Banque Worms can plausibly claim that its accidental receipt of payment from Security Pacific instead of from Spedley has not appreciably enriched it. Both consequences, of course, are dranatically altered by Spedley's insolvency.

When, by contrast, the third-party obligor is insolvent (as on the real facts of Banque Worms), an argument about discharge for value becomes an argument about whether the plaintiff's mistaken payment should shift the incidence of what would otherwise have been the defendant's credit loss. Here it may be useful to return to the inquiry suggested earlier, and to consider the parties' respective positions vis-à-vis the third-party obligor as a means of gauging the balance of equities between them. In the context of restitution between successive fraud victims, the fact that plaintiff and defendant are identically situated vis-à-vis the wrongdoer makes it (I have argued) extremely difficult to conclude that one has been unjustly enriched at the expense of the other. Discharge for value, in its typical scenario, presents a sharp contrast. Banque Worms's relationship with Spedley was based on the voluntary assumption of a credit risk, on terms (as to security and compensation) that Banque Worms found acceptable and that Banque Worms expected to be profitable. Secnrity Pacific's relationship to Spedley was, by contrast, merely one of agency: it undertook to transfer money in accordance with Spedley's instructions, not to extend credit. In these circumstances it seems relatively easy to conclude that Security Pacific's mistake has caused the unjust enrichment of Banque Worms, to the same extent as if the $\$ 2$ inillion had been directly but involuntarily contributed to the assets of the recipient bank.

142. In the case supposed, if Spedley does not pay voluntarily, Security Pacific has a claim in restitution against Spedley. Because Security Pacific has inadvertently discharged Spedley's debt to Banque Worms, Spedley is unjustly enriched at Security Pacific's expense, and Security Pacific is subrogated to Banque Worms's claim. 
If liability in restitution is based exclusively and unambiguously on the unjust enrichment of the defendant at the expense of the plaintiff, an affirmative defense to restitution that does not tend to refute the allegation of unjust enrichment is incongruous on its face. If the defense moreover lacks a compelling basis in commercial practice or other policy justification, it should be inadmissible to limit the restitution claim. Where money is paid by mistake, the commercial justification for a defense to restitution is the same as the commercial justification for bona fide purchase generally: the need to be able to rely on apparently good title (in this case, title to money). The court in Banque Worms was correct when it noted that commercial necessity must qualify the entitlement to restitution, but it failed to explain why the rejected New York rule (requiring a change of position on the part of the recipient) was not perfectly adequate to protect commercial reliance of the kind it described. The court, of course, did not even attempt to justify its result in equitable terms-to explain why one bank's clerical error should cause it to bear another bank's credit loss. Mistakes in future wire transfers will give courts the opportunity to reconsider the ironic proposition of the Restatement, and to decide whether liability in restitution for mistaken payments should not after all be "based upon the balance of justice between the parties," instead of "merely upon technicalities."143

143. See supra note 125. The same lack of curiosity about the balance of justice between the parties marks a subsequent decision on mistaken wire transfer, General Elec. Capital Corp. v. Central Bank, 43 F.3d 280 (7th Cir. 1995) (Easterbrook, J.). Here a debtor planned to defraud its secured creditor (GECC) by transferring the proceeds from a sale of collateral to its regular account at Central Bank, from which it could disburse them at will, rather than to an escrow account (also at Central Bank) controlled by GECC. A clerical error by an intermediary caused payment instructions to be truncated, and Central Bank credited the funds to the escrow account after all. When the debtor complained about the missing transfer, the original payment instructions were retrieved; Central Bank thercupon tried to correct its mistake by debiting the escrow account and crediting the debtor's rcgular account as initially directed. The debtor absconded with the funds. GECC sought to recover from Central Bank on the grounds that the debit to the escrow account was wrongful.

Central Bank had a claim in restitution against GECC to recover the mistaken payment, so the issue was whether GECC had a defense. Finding no precedent in the Wisconsin decisions for the application of "discharge for value," the court in this diversity case decided that Wisconsin would do well to adopt the rule-on the authority of Banque Worms, in the interest of finality in wire transfers, and in furtherance of the proposition that "[c]osts of errors should be bome by those who make errors (thc better to induce them to take care) rather than by innocent beneficiaries." Id. at 284. GECC was therefore entitled to retain the mistaken payment because it was received on account of a preexisting claim. The loss was left to be sorted out between the banks.

Taken on its own terms, the court's justification of the result is unsatisfactory. Granted, the recipient of a payment which he was expecting should not have to inquire into the chain of title; but why does the "innocent beneficiary" not obtain adequate protection from a defense of change of position? Discharge for value is critical only for recipients, like GECC, that have done nothing in reliance on the mistaken payment. The question whether it is more efficient that costs be "borne by those who make errors," rather than by a legal system that will occasionally rectify error, is of course an empirical onc (since the costs of error prevention might excced the costs of rectification); but supposing the court's contrary assumption to be correct, it proves too much, because it implies that we should have no restitution for benefits conferred by mistake when the law is plainly otherwise.

The greatest deficiency of this reasoning is still what it leaves out. Despite his somewhat condescending remark that "Wisconsin's cases bristle with references to 'equity and good conscience," 


\section{CONCLUSION}

The intellectual vitality of restitution in this country, and ultimately its continued existence as a recognized body of law, requires that judges and lawyers know what it is, how to use it, and how to argue about it. Anyone who reads through current law reports looking for restitution must notice that a substantial proportion of American restitution cases, perhaps a majority, are being argued and decided by lawyers and judges who do not adequately understand what they are dealing with. Even when legal issues are properly situated within the context of restitution, the technical competence of judicial opinions in the area is, all too often, strikingly low. Such are the predictable consequences of unfamiliarity. If present tendencies continue, the modern law of restitution-an American invention-will become a subject actively pursued in England and the Commonwealth but no longer comprehended by American lawyers. Pieces of doctrine will remain, dispersed as appendages to a dozen different subjects, but they will lack a central core of explanation to facilitate analogies and remind us what we're doing.

Before we can tell a straight story about restitution, we must decide what the subject is about. Is restitution the body of law concerned with avoiding unjust enrichment? Is it mostly that but partly other things as well? Or is the identification with unjust enrichment altogether an illusion, and restitution merely a hodgepodge of devices for undoing, unwinding, throwing into reverse, and giving thimgs back? My starting assumption has been that a law of restitution defined exclusively im terms of unjust enrichment offers such obvious practical advantages, measured chiefly in terms of coherence and accessibility, that the subject should be so defined if logic and case outcomes will permit us to do so. The short answer is that they will.

Rights and remedies not referable to unjust enrichment either find a better explanation elsewhere, or they signal restitution cases wrongly decided. Outcomes will change in a few marginal cases only, but those few are important; cases on the margin of a subject are the ones that define not only its scope but its rationale. More importantly, a clear focus on unjust

id. at 285, Judge Easterbrook was not really interested in thinking about what equity and good conscience might dictate in the case before him; he was confident that he had already identified (in finality and efficiency) superior grounds of decision. He is therefore uneoncerned that to allow a defense in Central Bank gives GECC a pure windfall as the result of a bank's clerical error. Nor does he trouble to consider how the parties were situated vis-à-vis the ultimate cause of the loss, though on the facts of Central Bank the perspective is a revcaling one. Denial of restitution shifts (to one of the banks) the consequences of a risk that GECC had agreed to bear: namely, the risk of the debtor's misconduct. GECC was paid to accept this risk; GECC negotiated the terms on which it would manage it (in its security agreement with the debtor); GECC was the only party in a position to police the debtor's behavior. The secured credit agreement, not the wire transfer, was the transaction that went seriously wrong in this case, yet to this transaction the banks were total strangers. Requiring them to bear a loss they could not control offends not only equity and good conscience but ordinary precepts of risk-spreading as well. 
enrichment as the exclusive basis of liability and measure of recovery in restitution should facilitate agreement and disagreement over the substantive issues - which noncontractual benefits have to be paid for, and how much? - allowing this intriguing area of the law to resume at last its interrupted development. 